\title{
Bilim Gazeteciliğinde Popülaritenin ve Pozitif Bilimlerin Hegemonyası
}

\author{
Onur DURSUN \\ Doçent Dr. \\ Çukurova Üniversitesi Illetişim Fakültesi \\ Gazetecilik Bölümü \\ odursun@cu.edu.tr, dursunonur@gmail.com \\ Orcid: 0000-0001-9268-0936
}

\section{Abstract \\ Hegemony of Popularisation and Positive Sciences in Science Journalism}

This study aims to explore the current situation and the problems of science theme in news/science news by focusing on science journalism in Turkey. It draws attention to the function of science in a society and mentions the contributions of scientific knowledge to democratization process and the possible harms could be caused by misuse. By presenting some aspects of science journalism, this study sets out to describe what science journalism is and investigates the problems of science journalism. The study attempts to reveal the problems through content analysis of five national newspapers namely Cumhuriyet, Hürriyet, Milliyet, Sabah, and Sözcü. Focusing on the fifteen-day-time period from 20 January 2018 to 03 February 2018, the study examines the science coverage of the newspaper samples under 5 main and 42 sub-categories. The analysis reveals that science coverage is not found to be quantitatively sufficient in the Turkish press, as the investigating news predominately focuses on such popular and positive sciences as medical/health, nature, technology, and archaeology.

Key words: Science journalism in Turkey, science communication, commercialization of science, publicization of knowledge. 


\section{Résumé}

\section{L'hégémonie de la vulgarisation et des sciences positives dans le journalisme scientifique}

Cette étude a pour but de déterminer l'état du contenu scientifique dans les médias en Turquie en se concentrant sur le fonctionnement actuel du journalisme scientifique. Notre étude porte sur l'importance des apports de la science sur la société et l'espace public, et la contribution que peut apporter la connaissance scientifique dans les processus de démocratisation et des dommages possibles causés par le mauvais usage. Puis, elle définit le journalisme scientifique en proposant ses différentes approches, et étudie par la même occasion ses problèmes. Notre étude tente de déterminer l'état du journalisme scientifique en analysant les nouvelles scientifiques des journaux Cumhuriyet, Hürriyet, Milliyet, Sabah et Sözcü. Dans cette étude, l'échantillonnage a porté sur la période du 20 janvier au 3 février 2018. Lors de notre étude, les informations aux contenus scientifiques éditées par les journaux faisant partie de l'échantillonnage sur une période de 15 jours ont été analysées sous 5 catégories principales et 42 sous-catégories, à l'aide des techniques d'analyse du contenu. II apparait, au vu des résultats de l'étude, un espace insuffisant attribué aux nouvelles scientifiques dans les journaux en Turquie, les nouvelles scientifiques présentes portant plus souvent sur les actualités de santé/médecine, de nature, de technologie, d'archéologie c'est-à-dire des sciences populaires et positives.

Mots clés : Journalisme scientifique, communication scientifique, journalisme scientifique en Turquie, commercialisation de la science, publicité de l'information. 


\section{Özet}

Bu çalışma bilim gazeteciliğinin günümüzdeki ișleyişine odaklanarak, Türkiye medyasındaki bilim içerikli haberlerin durumunu ve sorunlarını tespit etmeyi amaçlamaktadır. Çalışmamız, bilimin toplumdaki işlevine dikkat çekmekte ve bilimsel bilginin demokratikleşme süreçlerine sunacağı katkılar ile yanlış kullanımıyla oluşacak olası zararlara değinmektedir. Ardından bilim gazeteciliğine ilişkin farklı yaklaşımlar sunularak bilim gazeteciliği tanımlanmakta ve bilim gazeteciliğinin sorunlarını irdelemektedir. Çalışmamız Türkiye'deki bilim gazeteciliğinin durumunu Cumhuriyet, Hürriyet, Milliyet, Sabah ve Sözcü gazetelerinin bilim haberlerini analiz ederek ortaya koymaya çalışmıştır. Çalışmamızın örneklemi, 20 Ocak-03 Şubat 2018 tarihleri arasını kapsamaktadır. Çalışmada içerik analizi tekniği kullanılarak örneklemdeki gazetelerin 15 günlük süreçte yayınladıkları bilim içerikli haberleri, 5 ana ve 42 alt kategori altında analiz edilmiştir. Türkiye'de bilim haberlerinin gazetelerde yeterince yer alamadığı, mevcut bilim haberlerinin ise sağlık/tıp, doğa, teknoloji, arkeoloji gibi popüler ve pozitif bilimler ağırlıkı olduğu sonucuna ulaşılmıştır.

Anahtar Kelimeler: Bilim gazeteciliği, bilim iletişimi, Türkiye'de bilim gazeteciliği, içerik analizi, bilimin ticarileşmesi, bilginin kamusallaşması. 


\section{Giriş}

Bilim, toplumların rasyonelleşmesini ve demokratikleşmesini sağlayacak zeminleri inşa edebilecek güce sahiptir. Tarihsel süreç takip edildiğinde bilimsel bilginin yaygınlaşmasına paralel olarak toplumların geliştiği görülmektedir. 50 bin yılık insanlık tarihinin sadece son 5 bin yılına göz atılığında bile, kritik noktaların/ kırımaların/dönüşümlerin icatlara, coğrafi keşiflere, bilim hareketlerine, eğitim-öğretimdeki gelişmelere konumlandığı anlaşılmaktadır. Bilginin üretimi ve dağıtımı/ tüketimi öncelikle bireysel bilinçleri ve ardından bireysel bilinçlerin kümesi olan toplumu aydınlatarak dönüşüme uğratmıştır. Tarih, bu diyalektiğin sonucunda yazıımış, günümüzün demokratik ve eşitlikçi toplumlarına, kuşkusuz bilimsel hareketlerin sonucunda ulaşılmıştır. Bu nedenle bilimsel bilginin üretilmesi ve üretilen bilginin ise kamusallaştııılması önemlidir.

Giderek karmaşıklaşan günümüz toplumlarında yurttaşlar, gündelik yaşamın teknik-pratik sıradan sorunlarıyla mücadele edebilmek için bilimsel kaynaklardan gelen bilgilere ihtiyaç duymaktadırlar. Bu bilgi türü, yurttaşların sadece gündelik pratik işleri için değil, yönetimsel-siyasal süreçlere daha rasyonel biçimde katılım sağlayabilmeleri için de gereklidir. Kamusal alanda doğru kararların alınabilmesi, başka bir ifadeyle kamuoyunun daha sağlıkı bir şekilde oluşabilmesi için bilimsel bilginin kamusal alanda yeterli düzeyde dolaşıma girmesi önem taşımaktadır. Bu noktada bilim iletişimi/gazeteciliği devreye girmektedir. En azından bilim gazeteciliğinin böylesi bir potansiyeli yüksektir. Fakat bilim iletişiminin/gazeteciliğinin mevcut durumunun beklenen düzeyde olmadığı söylenebilir.

'Bilimin raflara kaldırıması', 'sırça köşkte bilim yapmak' sık sık duyduğumuz ifadelerdir. Bu ifadelerin gerçekliklerini -varsa şayet- yitirebilmesi için bilimsel bilginin kamusal alanda yeterli düzeyde dolaşıma girmesi ve toplumsal süreçlere katkı sunması gerekmektedir. Bilimi üretenlerin, dağıtanların ve tüketenlerin çeşitli sorunlarla karşılaştığı da doğrudur. Bu çalışmamın ilk bölümü, bilimin toplumsal faydalarından ve kullanımından kaynaklı doğacak zararlarından hareket etmiş ve buna bağlı olarak bilim gazeteciliğinin görevini, önemini ve şu anki durumunu/ sorunlarını kuramsal olarak betimlemeye çalışmıştır. Çalışmamızın analiz kısmında ise bilim içerikli haberlerin Türkiye basınındaki durumu tespit edilmiştir. Çalışmamı bilim içerikli haberlerin Türkiye medyasında niceliksel olarak yeterli olup olmadığını, bilim haberlerinin kaynaklarını, bilim üreten kurumlarla olan ilişkisini, hangi bilim alanlarının ön plana çıktığını, özet ifadeyle bilim haberlerinin Türkiye medyasındaki genel görünümünü resmetmeye çalışmıştır. Çalışmamızın araştırma tasarımına ilişkin bilgiler, analiz bölümünde ayrıntılarıyla yer almaktadır.

\section{Bilimsel Bilginin Üretilmesi ve Kamusallaştırılmasındaki İkili İşlev: Modernleştirme ve Tahakküm Kurma Aracı Olarak Bilim}

Bilim ve teknolojideki gelişmeler, yaşam şekillerini değiştirmekte, yeni endüstriler, iş kolları yaratmakta ve insanlara toplumsal ve çevresel sorunlarla mücadele etme olanağı sağlamaktadır. Tarihten günümüze bilincimizi, düşünme 
şeklimizi değiştiren, bilimsel bilgi/araştırmalar olmuştur (Royal Society, 2010, s. 4; Richter, 1995, s. 9-10, Gelmez Burakgazi, 2017). Bilimin toplumdaki görevine ve toplumun bilim algısına ilişkin önemli araştırmalardan birisi şüphesiz Royal Society tarafından 1985 yılında kurulan Committee for Public Understanding of Science[CoPUS])'ın hazırladığı ve Walter Bodmer'in rapora dönüştürdüğü Public Understanding of Science'tır (PUS). PUS, demokrasilerde kamuoyunun, karar alma süreçlerinde büyük bir etkiye sahip olduğunu ifade etmektedir. Rapora göre, karar oluşturucular kadar şahsi yurttaşlar da kamusal konularla ilgili bilimsel bakış açılarının farkına varabilmeli ve bu bakış açılarını anlayabilmelidirler. Çünkü yurttaşlar, çıkar grupları arasındaki rakip iddialar arasında akla yatkın kararlar oluşturabilmek için, birtakım temel bilgileri bilmeye ve sunulan kanıtların niteliğini belirleyebilme yeteneğine gereksinim duyarlar. Mevcut soruna ilişkin bilimsel bakış açılarını anlamak, en iyi cevabı oluşturmasa da en azından daha fazla bilgi sunarak daha iyi kararların alınmasına öncülük edecektir (Bodmer, 1985, s. 10; Sturgis \& Allum, 2004, s. 55-56; Brito vd., 2012, Gelmez Burakgazi, 2017, s. 236). Franklin'in (2007, s. 156) ifadesiyle, bilim uygarlığın yaşamsal ilkesidir. Bilim yapmak, eleştirel olmaktır; bilim savunusu ise siyasi realizmin özüdür.

Confederación de Sociedades Científicas de España (COSCE)'nın hazırladığı Acción CRECE (Science and Society) başıılı rapor bilimi, yaratıcıık ve ilerleme fikirlerinin miras olarak aktarıldığı entelektüel bir macera olarak nitelendirmektedir. Raporda bilim, modern kültürün parçası olarak değerlendirilmekte ve bilimin, dünyamıza ilişkin kavramlarımızı kökten değiştirdiği vurgulanmaktadır (COSCE, 2005, s. 135).

Bilgiyi kimin ürettiği ve hangi koşullarda ve ne amaçla kullanıldığı ya da kamusallaştııılığı da tartışılması gereken noktalardan birisidir (Bağlama, 2018, s. 160). Bilimsel bilginin üretimine ve tüketimine göz attığımızda karşımıza genel yargıları doğrulayan düşünceler çıkmaktadır. Avrupa Komisyonun hazırladığı rapor, başarıları her ne olursa olsun bilimin insan tarafından yapıldığını, her daim güç ve çıkarla bağlantı kurduğunu, sınırlarının bulunduğunu, toplumsal olarak tarafsız olmadığını belirtmektedir (European Commission, 2007, s. 4, 7-9).

Her bilim alanı kendi içinde çelişkiler barındırmaktadır. Teknoloji gelişmektedir ve kuş̧usuz gündelik yaşamı kolaylaştırmaktadır ama beraberinde bağımlııklar yarattığı, insanları özgürleştirme nosyonuyla yalnızlaştırdığı, insanları çeşitli denetim/gözetim mekanizmalarına mahkûm ettiği, teknolojiyi üretenlerin aynı zamanda dünyayı gözetlediği ya da savaşları teknolojilerin yönettiği gibi gerçekleri göz ardı edebilir miyiz? Doğa araştırmalarının doğayı tanımamıza ve kendimizi doğa koşullarına uydurabilmemize yardımcı olduğu doğrudur, ama doğayı kaynak olarak gören bilimsel araştırmaların topladığı bilgilerin kapitalist-üretim sürecine transfer edildiğini ya da bu verilerin sermaye çevreleri için fizibilite raporları niteliğinde olduğunu yadsıyabilir miyiz? Tıp, sağlık, ilaç sektörlerinde önemli gelişmelerin yaşandığı ve sürekli olarak bilimsel çalışmaların üretildiği, ama tıp/sağlık ve ilaç sektöründe holdinglerin/tekellerin oluştuğunu görmeme olanağımız var mı? Arkeolojik kazılarla elde edilen verilerin müzelerde para karşılığında sergilenmekten başka ne işe ya- 
radığı konusunda da toplum olarak henüz bir farkındalığımız oluşmuş değil (Thee, 1971, s. 367-370; Ben-David, 1971). İşletme, pazarlama, reklamcılık, tanıtım, halkla ilişkiler, siyaset bilim gibi piyasalarla ya da yönetimlerle bağlantılı bilim alanlarında üretilen bilgilerin neye hizmet ettiği tartışmalıdır. Baram (1971, s. 535), bilim ve teknolojinin toplumsal alana katkılarını irdelediği çalışmasında, bilimin ayın zamanda toplumsal kontrole tabi olduğunu belirtir. Bilginin üretim, dağıtım ve tüketim aşamaları birbiriyle çatışan noktalar barındırmaktadır. Her konum, kendi çıkarından hareket etmektedir. Öz ifadeyle bilimin üretiminden tüketimine ideolojiden kaçış olanaksızdır (Tobey, 1993, s. 103-108; Erdoğan, 2007, s. 19-22).

\begin{abstract}
Ideolojimizin kaynağı olan bilimsel çalışma öncesi bilişsel eylem, bilimsel çalışmamızın ön gerekliliğidir. Hiçbir yeni hareket, ideoloji olmaksızın gerçekleşmez. Bilimsel çalışmalarımızı veya benzeri şeylerimizi formüle etmek, savunmak ve saldırmak için argümanlarımızı ideoloji sayesinde elde ediyoruz. Olgularımız ve araçlarımız, kendisini bu süreçte büyütüyor ve yeniliyor. Ve böylece ideolojilerimiz sayesinde yavaş yavaş ilerliyoruz, onlarsız ilerleme sağlamamız neredeyse olanaksızdır (Schumpeter, 1949, s. 359).
\end{abstract}

Elias (2007, s. 227-228), yaşanacak herhangi bir doğal-toplumsal felaket karşısında, aşağıda sıralanan halkla ilişkiler stratejileriyle bilimin politik bir araca dönüştürüldüğünü düşünmektedir. Bilimin politikleşmesi, kuşkusuz bilimsel tahakkümü beraberinde getirmektedir:

Bilimsel olmayan ölçüt temelli atama: bilim danışma komitesine atamalar, bilimsel uzmanlıktan daha ziyade siyasi sadakate göre yapılmaktadır. Kamusal iletişimin merkezileşmesi: tavsiye kurulu başkanı, kitle medyasının tek yetkili kaynağıdır.

Bilgilendirmeden daha ziyade besleme: yayınlanan raporlar, zamanında ve yeterli biçimde kamuyu bilgilendirmekten daha çok bilgi açısından gazetecilik intiyaçlarını tatmin etmekte ve beslemektedir.

Bağımsız kaynakların güvenini sarsma: kitle medyasına açıklama yapan bağımsız bilim insanlarına saldırımakta ve uzmanlıklarına gölge düşürülmektedir. Devletin bilim insanları, üstlerinden izin almadan bağımsız açıklama yapamamaktadır.

İlgili verilere ulaşımda kısıtlama: tayin edilen komite, güncel veri ve bilgilere erişimi kısıtlamaktadır.

Bilim insanları, yöneticiler ve politika belirleyiciler arasındaki iletişim ilişkilerinin birbirlerine meydan okuyucu niteliğinin devam ettiğini belirtmemiz gerekmektedir (Brito vd., 2012, s. 2). Bilimsel alanın devletin güdümünde olması ya da bilim insanlarının dönemsel olarak yönetimlerce yönlendirilmesi (Gunnell, 2009, s. 318, 320) dünya genlinde bir sorundur. Dünyanın birçok ülkesinde bilim devlet tarafından yönlendirilmekte ve aynı zamanda dünyayı da yönetmektedir (Fuller, 1999, s. 8; Angler, 2017, s. 14; Egikova, 2009, s. 31). Bilindiği üzere bilimin üretim merkezi genel olarak eğitim kurumlarıdır ve dünyanın hemen hemen her ülkesinde eğitimin büyük oranda devletin elinde olması, bilimsel üretimin ve bilimsel kontrolün de devlet güdümünde olduğunun göstergesidir. 
Bilimin devletten bağımsız kurumlarca üretilmesi, bilimin bağımsızlığını ilan etmesi anlamına gelmemektedir. Özel üniversiteler, şirketler, organizasyonlar, sivil toplum kuruluşları gibi birçok oluşum, bilim üretim sürecine dâhildir. Söz konusu yapıların ürettiği bilimsel bilginin kendine özgü amaçları, hizmet ettiği çevresi vardır (Cook vd., 2009). Bu noktada, Fjæstad'ın "bilim lobisi" ifadesi oldukça aydınlatıcıdır. Fjæstad, bilim lobisinin, bilim için daha fazla paranın peşinde koşan, bilim içinde parayı kontrol eden, projelerin, metotların, prosedürlerin seçimini bilimsel kontrol içinde yapan insanları içerdiğini belirtir. Bu kişilerin mantıksal başarılar elde etmeye çalıştıklarını ve toplumdan fazla bir beklentilerinin olmadığını düşünen Fjæstad'a göre, bu insanların medyayla ilgilenme/medyayı kullanma nedenleri, böylesine amaçlarını ileriye taşımaktır. Ama bu kişilerin bakış açılarından, yaptıkları iş lobicilik değildir. Onlar, topluma faydalı olduklarını, bireysel refaha ve demokratik sürece yararlı olacak bilgilerin yayılmasını sağladıklarını ve kültürel katkı sunduklarını düşünmektedirler. Bilimle para kazanmak yasal ya da temel demokratik bir hak olarak görülebilir. Ancak akademideki birçok insan için reklamcılık, halkla ilişkiler, lobicilik onaylanamaz niteliktedir ve bilimsel etkinlikten ziyade ahlaki değersizliktir (Fjæstad, 2007, s. 125-126; Fuller, 1999, s. 22-23).

Bağımsız bir bilim gibi bağımsız bir gazetecilik de demokrasinin can damarıdır. Ancak halkla ilişkiler uzmanları gibi piyasa profesyonellerinin destekleriyle oluşturulan bilim içerikli haberler, kamuyu bilgilendirmekten daha ziyade kapitalist piyasayı, hissedarları bilgilendirmeyi amaçlamaktadır. Bilim haftaları ve bilim festivalleri gibi kamusal etkinlikler, bilim ve kamu arasındaki etkileşimi geliştirmeyi amaçlarken, bu etkinliklere sponsorluk eden kuruluşlar bu etkinlikleri kamusal formdan ticari şova dönüştürerek (Bauer and Gregory, 2007, s. 48, Yıldırım Becerikli, 2013a) bilimin özüne zarar verebilmekte ve bilim ile bilim gazeteciliğine olan güveni sarsabilmektedirler (Göpfert, 2007). MIT Öğretim Üyesi Rehman'a göre (The Guardian, 16 MayIs 2013), birçok bilim haberi, 'bilgi-reklam' kategorisine girebilecek niteliktedir, bu nedenle eleştirel bir bilim gazeteciliğine gereksinim vardır.

Bu eksende tartışıması gereken diğer bir nokta ise popüler bilimdir. Popüler bilim içerikleri tarihin çeşitli evrelerinde farklı formlarda karşımıza çıkmaktadır. Geleneğin temelleri 18. yüzyılda atılmış ve o dönemlerde almanaklar, romanlar, teatral metinler, gazete makaleleri gibi çeşitli yazınsal formlarla varlığını sürdürmüştür. Günümüzde ise genel olarak kitap, dergi, televizyon vb. araçlarla gündelik yaşamda yerini almaktadırlar. 20. yüzyılın bilim tarihi, ABD, İngiltere gibi ülkeler başta olmak üzere Avrupa bağlamında incelendiğinde popüler bilim kitaplarının yayıncılık piyasasında ya da piyasanın genelinde önemli bir paya sahip olduğu anlaşılmaktadır. Bu kitapların alanı şüphesiz, fizik, astronomi, doğa vb. bilim dallarının da içinde yer aldığı fen/pozitif bilimler alanıdır. Aslında evreni, uzayı, gezegenleri, yıldızları, yeryüzünü, doğayı, canlıları bilimsel olarak keşfeden popüler bilim kitaplarının sözü hâlâ geçerlidir. Bu yayınları tümüyle anti-bilimsel ya da yararsız görmek doğru değildir. Gündelik yaşamda, bilhassa da 19. yüzyıl Avrupa'sında insanların bazı gereksinimlerini ucuza karşıladıkları da olmuştur (Turney, 2007, Govoni, 2007, s. 21-23, Sheets, 1985). 
Bilimin topluma sunduğu faydalara değinin çalışmalar kadar bilimsel bilginin kullanımıyla oluşacak anti-hümanist tutumları anlatan çalışmalar da mevcuttur. Tabii, bilimin veya bilimsel bilginin ne olduğunu tanımlayacak kati kurallar bulunmamaktadır. Bilim yaptığını iddia eden herhangi birini ya da herhangi bir oluşumu irdelememizi sağlayacak bilimsel ölçütler nelerdir? Üniversitelerin ürettiği bilgi ile şirketlerin ürettiği bilgi arasında fark var mıdır? Devletin ürettiği bilgi ile bağımsız kuruluşların ürettiği bilgi aynı şey midir? Deney ve gözlemle elde edilen bilgileri bilimsel olarak nitelendiren birisi, pazar araştırmalarıyla tüketici tercihi ya da memnuniyeti ölçen araştırmaları neye dayanarak bilimsel bulmayacaktır? Bu soruları cevaplamak hem kolay hem de bir o kadar zordur. Ancak bilimsel bilginin niteliğini kullanım amacının belirleyecek olması en makul olanıdır. Insanlığa faydalıysa, evrensel olan iyiyi özendiriyorsa o bilgi 'bilimsel' niteliğini hak etmelidir.

\section{Bilimin Kamusallaşma Aracı Olarak Bilim Gazeteciliği ve Sorunları'}

Bilim gazeteciliğiyle ilgili çeşitli tanımlar mevcuttur. Bilim gazeteciliğinin/ haberciliğinin ne olduğuna ilişkin üzerinde uzlaşıya varılmış bir tanım mevcut değildir. Bilim ve kamu arasındaki ilişkilerin değişimi, bilimsel paradigmada yaşanan dönüşümler, iletişim araştırmalarının eleştirel içerik kazanması gibi olgular bilim iletişimi/gazeteciliğinde, özellikle 90'lı yıllar sonrasında farklı yaklaşımların gelişmesine neden olmuştur (Dursun, 2010, s. 2). Vestergård (2016, s. 29), çaıışmasında bilim haberlerine ilişkin farklı yaklaşımları derlemiştir. Vestergård'a göre, yaklaşımlardan bazıları bilim haberlerini daha geniş bir tanım çerçevesine yerleştirerek bilim haberlerini bilimsel kaynaklara atıfta bulunan herhangi bir içerik olarak tanımlamaktadır. Bazıları ise daha yapısalcı yaklaşım sergileyerek, \% 50'sinin bilimsel bakış açılarına dayandığı içerikleri kapsayan makaleler olduğunu düşünmektedir. Amerika'daki çalışmaların büyük bir kısmı, daha yorumsal bir tanımı benimsemekte ve bilimsel alanlarla ilgili medya içeriklerini kapsayan makaleler/ içerikler tanımına ulaşmaktadır. Bazı yaklaşımlar, bilim haberlerinin, bilim alanlarının tümünü kapsadığını ifade ederken bazıları da doğaya dair sadece basit haberleri içeren medya içerikleri yorumunu yapmaktadır. Bilim haberlerini makalelerden ibaret gören; söyleşiler, köşe yazıları, soru-cevap teknikleri, okurlardan gelen yorumlar gibi birçok içeriğin bilim haberciliği kapsamında değerlendirilebileceğini savunan yaklaşımlar da mevcuttur. Bu yaklaşımlar, özü itibariyle bilimsel araştırmalarla elde edilen verilerin basın-yayın yoluyla kamusallaştıııması ve böylece kamuyu bilimsel süreçlerden haberdar ederek bir farkındalık/rasyonalite yaratması düşüncesinden hareket etmektedir (Treise ve Weigold, 2002, s. 311; Lieverouw, 1990; Nelkin, 1995; Treise and Weigold, 2002; Burns, O'Connor ve Stocklmayer, 2003; Shäfer, 2010, Dursun, 2010, Yıldırım Becerikli, 2013a). Tabii bu süreçte medya, toplumun bilime yaklaşımını da şekillendirmekte ve kamuya bilimi ve bilimin nasıl işlediğini öğreterek kamuda bir bilim düşüncesi inşa etmektedir. Bu da

1 Ayrıntılı bilgi için bkz. Utma, S. (2015); Bilim İletişimi ve Bilim Gazeteciliği: Ege Üniversitesi Haber Ajansı Örneğinde Üniversitelerde Bilim Haberlerinin Üretilmesine Yönelik Bir İnceleme, Ege Üniversitesi Sosyal Bilimler Enstitüsü Gazetecilik Anabilim Dalı, Yayınlanmamış Doktora Tezi;

Erdoğan, I. (2007). Türkiye'de Gazetecilik ve Bilim Illetişimi, Yapısal Özellikler, Sorunlar ve Çözüm Önerileri, G. Ü. İletişim Araştırmaları Merkezi Kırkıncı Yıl Kitaplığı No: 7. Ankara. 
kuşkusuz resmî ideolojiden bağımsız gerçekleşmemektedir (Summ \& Volpers, 2015, s. 776-778; Mercalfe \& Gascoigne, 1995, s. 412, Yıldırım Becerikli, 2013b).

Bilim gazeteciliği, diğer bütün gazetecilik türleri gibi bir türdür. Bu türlerle aynı kurallara tabi olan bilim gazeteciliği, eleştirel düşünmeyi gerektirmektedir. Angler'a (2017, s. 23) göre bilim gazeteciliği, karmaşık bilimsel kavramları irdelemeyi ve görevini istismar eden bilim insanlarını hesap verebilir kılmayı amaçlamakta ve bilimsel alanın derinlemesine anlaşılmasını sağlamaktadır. Okurların eğitim yaşamlarındaki tatsız deneyimlerinden kaynaklı bilimsel makaleleri okumayı reddetme sorununa bilim haberciliği aracıı̆ğıla medya yetişmiş ve bilimin karmaşık anlatı yapısını kamusal dile tercüme ederek kısmen çözüm olmuştur (Pitrelli, 2017. 41, Yıldırım Becerikli, 2013a, 2-3).

Bucchi ve Mazzolini'ye (2007, s. 54) göre bilim gazeteciliği, mühendislik ve tıp gibi doğa ve uygulamalı bilimlerle ilişkili bulguların ve olayların açık bir şekilde bilgisini veren ve bilim ve bilim temelli argümanlara referansta bulunan ve bilim uzmanları tarafından yapılan açıklamaları karakterize eden makaleleri kapsamaktadır. Klasik anlamda bilim gazeteciliği, bilimsel sonuçlarla, kurumlarla, süreçlerle, teknolojilerle ve tıpla ilişkilidir. Temel ortamı ise akademik dergilerdeki yayınlar, konferanstaki sunumlar, ödüllerdir (Nobel Ödülü gibi). Bilim haberleri, tsunami gibi doğal vb. felaketlerin faktörlerinin bilimsel açıklamaları gibi gündelik yaşamın ilginç olaylarından ya da genel haberlerden oluşurlar (Wormer, 2008; Dunwoody, 2014, s. 30-31).

The Washington Post'un bilim haberleri editörü Brauchli, iyi bir bilim haberinin tekil bir haber anlatımından öteye geçerek karmaşık kavramları ve prosedürleri açıklamak amacıyla grafik kullanması, okuyucuların sorunlarını yanıtlamaya hazır olması ve geleneksel haber anlatısını geliştirici videolar ve fotoğraflara yer vermesi gerektiğini düşünmektedir. Ona göre iyi bir bilim haberi anlatısı okuyucuları bilgilendirirken eğlendirmelidir de (The Washington Post, 25 Haziran 2009). O'Neill (1991, s. 184), bilim gazeteciliğini, iyi yapılandırılmış modern toplumun devrelerindeki kusurlu bağlantıları sağlamlaştırmaya yardımcı olacak genel amaçlı bir lehim olarak tanımlamaktadır. Bilim insanlarını, teknoloji uzmanlarını, iş insanlarını, bürokratları, eğitimcileri, öğrencileri ve vatandaşları birbirine bağlayan sistem etrafındaki fikir, enerji ve para akışını rahatlatacağını dile getirmektedir.

Kuşkusuz bilim gazeteciliğinin mevcut durumunu, sözde toplumsal fayda düşüncesinden hareketle tümden onaylamamız mümkün değildir. Hedef kitlenin popüler beklentileriyle, diğer bir ifadeyle piyasacı bir düsturla şekillenen, siyasi bağımlılıklarını gözeten kitle medyasının birçok alanı gibi bilim gazeteciliği de sorunlu ve yetersizdir. Bilimin medyadaki temsili, gazetecilerin ilgilerini yansıtmaktadır. Bu ilgi kamusal ilgiyle doğrudan bağlantıııdır. Bilimi kamusallaştırmayı amaçlayan ilk girişimler, bilim gazetecilerinin rolünü, davranışlarını ve normlarını tayin etmiştir (Nelkin 1987, s. 17, Uysal, 2017, s. 56, Utma, 2017). Bilim gazeteciliği, bilimin ölçütlerince değil de medyanın iktisadi-siyasi-kültürel yapısının talepleri doğrultusunda (Uysal, 2017, s. 32) kurumsallaştığından medya ve bilim arasında, medyanın beklentilerine daha yakın bir yere konumlanmıştır. 
Bilimin kitle medyasıyla kamusallaşmasının izleri 17. yüzyıla kadar uzanmaktadır ama asıl kurumsallaşma 20. yüzyıl boyunca, bilimsel gelişmelere paralel yaşanmıştır (Dunwoody, 2014, s. 28, Nelkin, 1987; Dursun, 2010; Yıldıım Becerikli, 2013a). Örneğin bilim muhabirleri, ABD'de 1900'lerde olağanüstü insanlar olarak nitelendirilmiş, 1930-1940'I yıllarda toplumun kurtuluşunun bilim olduğu konusunda kamuyu ikna eder bir rol üstlenmiştir. 1950'lerde bilim politikaları ve toplumsal etkilerinden daha çok bilimsel keşiflerin ayrıntılarına yönelmiş, 1960'larda bilim insanlarının siyasi tarafsızıklarını ve güdülerini sorgulayan avukat rolüne bürünmüştür. 1970'lerde çevreci hareketlere sempati duymuş, 1980'lerde reklamcı bir tarz benimserken, 1990'larda tekrardan eleştirel tavra dönüş yapmışlardır (aktaran Fahy ve Nisbet, 2011, s. 781-782; Trench, 2007).

Bilim gazeteciliğinin karşı karşıya kaldığı çeşitli profesyonel ve kurumsal sorunlar söz konusudur. Zaman baskısı, güvenilir kaynak bulma, haber hikâyelerine alan açma, bütçe, personel azlığı ve ticarileşmenin giderek artması temel sorunlar olarak sıralanabilir. Ayrıca gazeteciliğin giderek internete kaymasından dolayı, bilim gazetecilerinden teknolojik anlamda çoklu yetenekler talep edilmekte ve sınırlı kaynaklarla kısa zamanda daha fazla iş üretmeleri istenmektedir. Bu durum aslında bilim haberciliğinde bilim muhabirlerinin niteliksizliği gibi önemli bir sorunu da gündeme getirmektedir. Hedef kitlenin bilgilenmek için bilim haberlerini nasıl kullanacağına ilişkin endişeler de bilim muhabirliği açısından sorun teşkil etmektedir (aktaran Secko vd. 2013, s. 62-63; Utma, 2017, s. 791).

Schafer, bilim içerikli haberleri birbirinden farklı işleyişlere sahip "popülerleşme" ve "modernleştirme (mediatization)" şeklinde ikiye ayırmaktadır. Popülerleşme durumunda yazılan içerikleri, bilim insanları arasındaki iletişime işaret etmekte ve bilim içerikleri, medyanın hedef kitlesi düşünülerek hazırlanmamaktadır. Popülerleşme durumu, bilim insanlarınca teşvik edilmekte ve içerikleri, toplumsalla doğrudan bağlantısı olmayan bilimsel kaynaklara ve başlıklara dayanmaktadır. Bu gibi haberler genelde gazetelerin bilim sayfalarında yer almaktadır. Modernleştirme durumunda üretilen bilim içerikleri ise aksine, siyasi aktörler, kamu dışı organizasyonlar ya da yurttaşlık meseleleriyle ilgili bilimsel konular üzerine tartışmaları içermektedir. Bu tür içerikler, bilimsel bulguların sunulmasıyla ilgili değildir, bu nedenle de bilim sayfalarında yer almazlar ve bilim gazeteciliği alanında uzman olmayan gazetecilerce yazılırlar.

Bucchi ve Mazzolini, gündelik basının bilim içerikleriyle ilgili bir "düalizm" düşüncesinden hareket etmektedirler. Bir kutupta "bilimin popülerleşmesi", diğer kutupta "haber olarak bilim" yer almaktadır. IIlkiyle ilgili içerikler bilim ve sağlık sayfalarında yer alırken, ikincisiyle ilgili içerikler haber sayfalarında bulunur. Peters da çalışmasında, bilimden yararlanan gazeteciliği ikiye ayırır: Gazetecilerin tercih ettiği bakış açısı ya bilim-yönelimlidir ya da sorun yönelimli (aktaran Summ ve Volpers, 2015, s. 777). Diğer bir ikilik ise kesinlik ve görecelikten kaynaklanmaktadır. Gazeteciler, olasılıklar üzerinden hareket etmezken, bilim tüm ihtimalleri göz önünde tutar. Medyanın kendine özgü özerk dünyasında, gerçeklik göreceli değildir, ama bilim, mutlakıyetten hareket etmemektedir (de Semir, 2000, s. 125). 
Bilim haberlerine ilişkin diğer önemli bir nokta ise bu haberlerin hangi sayfalarda yer bulduğudur. Bilim haberlerinin büyük bir bölümü bilim sayfaları dışında yayınlanmaktadır. Örneğin Yunanistan medyasında, bilim-teknoloji haberlerinin \% 40'ı haber sayfalarında yayınlanırken \% 30'u bilim sayfalarında yer bulmuş, \% 14'ü ise çeşitli bölümler altında yayınlanmıştır (Dimopoulos ve Koulaidis, 2002, s. 230). Hijmans ve arkadaşlarının (2003, s. 159) Hollanda basınında yaptığı araştırmada bilim haberlerinin \% 67'sinin haber sayfalarında, \% 11'i bilim sayfalarında, \% 22'sinin ise diğer sayfalarda yayınlandığını göstermiştir. Almanya basınının 2003/2004 ve 2005/2006 yıllarını kıyaslayan araştırma, bilim içerikli haberlerin bilim sayfalarının dışında yükselişe geçtiğini göstermiştir. 2003/2004 yılındaki 414 (\% 25) bilim haberi sayısı 2005/2006 yıllarında 977'ye (\% 40) yükselmiştir (Elmar vd., 2008, s. 882-883). Bizim çalışmamızın örneklemini oluşturan gazetelerde bilim sayfalarının bulunmadığını, bilim haberlerinin çeşitli sayfalarda kendilerine yer bulabildiğini belirtmek gerekmektedir. Tiryaki'nin 2018 yılında Türkiye'deki bilim haberlerine ilişkin yaptığı araştırma ise bilim haberlerinde kaynak sorununu ortaya koymuştur. Araştırmaya göre bilim haberlerinin \% 68,5'inde kaynak belli değildir, kaynağı belli olan bilim haberi oranı ise \% 31,5'tir.

Bilim haberciliği açısından diğer bir sorun ise, bazı bilim dallarının daha hegemonik olmasıdır. Son yıllarda özellikle sağlık ve teknoloji haberleri ön plandadır. Bu durumun belirgin nedenleri arasında medya endüstrisinin, artan kamuoyu ilgisini karşılamaya çalışma çabası; sağlık ve teknoloji alanındaki firmaların medyada görünür olma isteği; medya sahiplerinin bu alandaki yatırımları yer almaktadır. Doğa bilimlerinin egemenliği aslında yaşam bilimlerinin, yani biyomedikal bilimlerin egemenliğinden kaynaklanmaktadır. Doğayı bilimsel olarak inceleyen bir makalenin, biyomedikal disiplinlere göre haber olma ihtimali daha düşüktür (Elmar vd., 2008, s. 884; Summ and Volpers, 2015, s. 779; Russell, 2010, s. 13). İtalya özelinde bilim iletişimi/gazeteciliği üzerine yapılan araştırma, bilim içeriklerinin sosyal bilimleri dışladığını, ağırlıklı olarak doğa, sağlık, tıp, teknoloji, mühendislik gibi fen/pozitif bilimler alanındaki bilimsel çalışmalarla ilgilendiği sonucuna ulaşmıştır (Bucchi and Mazzolini, 2007, s. 65-68). Schäfer'ın (2000, s. 655) araştırması da doğa disiplinlerinden herhangi birine odaklanan medya çalışmalarının oranının, bütün disiplinler içinde \% 93 olduğunu ve doğa disiplinlerindeki sıralamanın ise biyoloji, biyoteknoloji çalışmaları, klonlama, gen, kök hücre incelemeleri, tıbbi ve iklim değişikliği araştırmaları şeklinde devam ettiğini göstermiştir.

Gazetecilik daha orta-alt sınıf düzeyli bir kamu varsayımından hareketle içeriklerini oluşturmaktadır. Bilim ise orta-üst sınıf bir kitlenin anlayacağı düzeyde ilerlemektedir. Bilim insanları medyanın bilimi basitleştirebileceği, haber editörleri ise bilimsel jargonun medya içeriklerini genel-kamunun anlayabileceği düzeyden uzaklaştırabileceği endişeleri bilim gazeteciliğinin başka bir sorunudur. Bilim gazeteciliğiyle ilgili yapılan çalışmaların geneli, bilim ile medya arasında birbirini dışlayan ilgilerin olduğuna dikkat çekmektedir. Örneğin Fjæstad'a göre (2007, s. 127-128), bilimin amacı, araştırma sonuçlarını, öğretimi yaygınlaştırmak ve bilim için halkla ilişkiler yürütmek iken, gazetecilerin amacı haber vermek, teşhir etmek, geniş kitlelere 
ulaşmaktır. Bilim insanları, bilgileri yavaş yavaş yayarken gazeteciler hızlı bir şekilde yaymaktadır. Bilim insanları, hakiki bir oryantasyona sahipken, gazetecilerin oryantasyonu bireyseldir. Bilim insanları, rasyonel referanslarla hareket ederken gazeteciler duygusal referanslarla hareket etmektedir. Bilimde en iyi manzara uzlaşıyla oluşturulurken, gazetecilikte en iyi manzarayı farklı sesler resmetmektedir. Bilimde kuramsal, gazetecilikte pratik ilişki önemlidir. Bilim ayrıntıya önem verirken gazeteci için ayrıntı önemli değildir. Bilim insanları nitelikli sonuçlar için uğraşırken, gazeteciler sonuçları abartır. Her ikisinde de yapılan işler meslektaşlarca değerlendirilmekte ve böylece de güçlendirilmekte ve yeniden üretilmektedir. Fjæstad'a göre (2007, s. 128), bilimde yenilik, doğruluk ve ilginçlik gibi bir sıralama takip edilirken, haber medyasında yenilik, ilginçlik ve doğruluk gibi bir sıralama ön plandadır.

Bilim haberciliğinin diğer bir sorunu ise niteliği düşük bilimsel çalışmalara odaklanmasıdır. Borkar ve arkadaşlarının (2014), tıbbi bilimsel çalışmalar üzerine yaptıkları araştırma, tıpla ilgili bilim içerikli haberlerin çoğunluğunun gözlemlere dayanan çalışmalardan üretildiğini, etki faktörü yüksek dergilerden az sayıda bilim haberi oluşturulduğunu, gözleme dayalı çalışmalardan ise kalitesi ve yöntembilimi zayıfların tercih edildiğini göstermiştir. Akademik dergiler, çoğunlukla özel alanlarda çalışan bilim insanlarınca takip edilirken az sayıda insan bu dergilerin genel okuyucusudur. Akademik dergilerin niteliği görece yüksek olsa da muhabirler bu dergileri kaynak olarak kullanmamaktadırlar. Bunun en belirgin nedeni, akademik dergilerin, basın bildirilerine yer vermemesidir. Kuşkusuz Science Citation Index'te puanları yüksek akademik dergileri muhabirler açısından kullanışı kılan çeşitli faktörler de mevcuttur. Bunlardan ilki, "popüler" akademik dergilerin birçoğunun yayın içeriğinin genel olması ve geniş bir yelpazede bilimsel başlıklar içermesidir. Ama haberde yenilik kriterini yerine getirememelerinden dolayı haber pazarında muhabirler için kullanışlı olamamaktadırlar (de Semir, 2000, s. 127).

Kitle iletişiminin, bilimsel bilgiyi yanlış yorumlayabilme olasılığı yüksektir ve bu da bilim gazeteciliğinin sorunlarından birisi olarak karşımıza çıkmaktadır. Yanlış yorumlar, çeşitli faktörleri gündeme taşımaktadır. Özellikle sansasyonel haberler oluşmakta, bilimsel konularla ilgili haberlerde analiz ve bakış açısı yoksunluğu ortaya çıkmakta, haber seçiminde çeşitli profesyonel dergilere aşırı güven sergilenmekte, güçlü kaynakların eleştirisinde eksikliklerle karşılaşılmakta ve bilgiyi değerlendirme sürecinde kriter yoksunluğu oluşmaktadır (de Semir, 2000, s. 128).

De Semir (2000), gazetelerin kapitalist beklentiler doğrultusunda hareket ettiğini düşünmektedir. Bilimsel gerçeklik ile haber medyasının algıladığı gerçeklik arasındaki farklara dikkat çekmektedir. Bu alanda yetişmiş muhabirlerin ya da haber editörlerinin bulunmamasını eksiklik olarak nitelendirmektedir. Haber medyasının bilim içerikli haberleri sunarken, ilgi çekici noktalara yöneldiğine değinmektedir. Gazetelerde bilim sayfalarının olması gerektiğini belirten de Samir, uzmanlaşmanın gerekliliğini vurgulamaktadır. Medyanın hızlı olması, ama buna karşın bilimsel bilginin çabuk üretilememesi arasındaki ilişkinin sorun yarattığını düşünen de Semir, medyanın bilim haberlerini sunarken, içeriği kamusallaştırma- 
dan önce kendi hakikatine çevirdiğini, kamuya bilimsel hakikati değil, kendi bakış açısından doğan hakikati aktardığını ifade etmektedir. PUS ise editörlerin bilimsel alt yapılarının bulunmayışına dikkat çekmekte ve bilim haberi editörlerinin yetiştirilmesini önermektedir (Bodmer, 1985, s. 21; Alda, 2010). Bu nedenlerden ötürü bilim insanları ile gazeteciler arasındaki ilişkiler, bilimsel bilginin kamusal alanda anlaşılır biçimde dolaşıma girebilmesi için geliştirilmelidir (Kennedy, 2010, s. 4).

\section{Analiz ve Bulgular}

\section{Araştırmanın Örneklemi ve Zaman Aralığı}

Bu çalışmanın örneklemini Cumhuriyet, Hürriyet, Milliyet, Sabah ve Sözcü gazeteleri oluşturmaktadır. Bu gazeteler örnekleme dâhil edilirken üç kıstas dikkate alınmıştır. Bunlardan ilki tiraj, ikincisi gazetenin kuruluş tarihi, üçüncüsü ise genel yayın politikasıdır. Hürriyet (1948), Sabah (1985) ve Sözcü (2007) gazeteleri, araştırmanın yapıldığı dönemde en çok satan ilk üç gazetedir. Bu gazetelerden Hürriyet liberal kanadı, Sabah sağ kanadı, Sözcü ise ulusal kanadı temsil etmektedir. Bu nedenle söz konusu gazeteler örnekleme dâhil edilmiştir. Milliyet (1950) gazetesi tiraj olarak 7. sırada yer almaktadır, ancak gazetenin şu anda yayın hayatını sürdüren en köklü 3. gazete olmasından ve liberal-sağ kanadı temsil etmesinden dolayı örnekleme dahil edilmiştir. Cumhuriyet (1924) ise Türkiye'de yayın hayatını sürdüren en eski gazetedir ve ulusal-sol kanadı temsil etmektedir. Bu nedenle çalışmamızın kapsamına alınmıştır.

Araştırmamız 20 Ocak - 03 Şubat 2018 tarihleri arasını kapsamaktadır. Bu tarih aralığı, gündemin görece daha boş olmasından dolayı tercih edilmiştir. Çünkü gündem olarak yoğun tarihlerde yapılan araştırmalar farklı sonuçların çıkmasına neden olabilmektedir. Ayrıca araştırmada örneklemin güncelliğine de dikkat edilmiştir. Araştırmada köşe yazıları ve spor sayfaları örneklem dışı tutulmuştur. Ayrıca ilan sayfaları, "bu bir ilandır", "ilan sayfası" gibi ibarelerin bulunduğu sayfalardaki bilim haberleri de dikkate alınmamıştır. Çalışmamız, belirli bir periyoda sahip köşe yazıları dışındaki her türlü haber metnini dikkate almıştır. Araştırmada ana gazete dikkate alınmış, her türlü ek örneklem dışı bırakılmıştır.

\section{Araştırmanın Tekniği ve Kategorileri}

Araştırmada içerik analizi tekniği kullanılmıştır. Ön incelemeler sonucunda 5 ana kategori altında 42 alt kategori belirlenmiş̧ir. Bu kategoriler aracılığıyla bilimsel nitelikli haberleri çeşitli açılardan değerlendirilebilmiş ve haberin bilim alanı, kaynağı, kurumsal dayanağı, kurumsal dayanağın statüsü ve yükseköğretim kurumlarıyla bağlantıları tespit edilmiştir. Ana kategoriler ve bu kategorilerin alt kategorileri şöyledir:

- Haberlerin Bilim Dalı: Bu ana kategori, "Doğa/Çevre, Edebiyat, Eğitim, Ekonomi, Felsefe, Fizik, Hukuki Meseleler, Kimya, Matematik, Psikoloji, Sanat, Siyaset, Tarih/Arkeoloji, Teknoloji, Tıp/Sağlık, Yaşam/ 
Kültür ve Diğer" olmak üzere 17 alt kategori içermektedir.

- Haberin Bilimsel Kaynağı: Bu kategorinin altında "Araştırma, Basın Açıklaması, Bilimsel Toplantı, Bilimsel Yayın, Bireysel Açıklama, Kitap, Proje/Program, Rapor, Veri ve Diğer" olmak üzere 10 alt kategori oluşturularak haberlerin hangi bilimsel kaynağa/etkinliğe dayandığı belirlenmeye çalışılmıştır. Bu kategorilerin belirlenmesinde haberler yönlendirici olmuştur. Çünkü haberlerde "yapılan araştırmaya göre", "rapora göre", "verilere göre", "açıklamaya göre" gibi ifadeler sıklıkla kullanılmaktadır. Ancak hepsini bir kategori altında toplamanın sağlıklı sonuçlar vermeyeceği düşünüldügünden her biri ayrı kategori olarak tasarlanmıştır.

- Bilim Haberlerinin Kaynağının Kurumsal Statüsü/Niteliği: Bu kategori, haberin bilimsel kaynağının dayandığı kurumun statüsünü tespit etmeyi amaçlamaktadır. Kategori kendi içinde "Türkiye Kamu Kurumları, Türkiye Kamu Dışı Kurumlar, Yurtdışı Kamu/Kamu Dışı Kurumlar, Uluslararası Statülü Kurumlar/Kuruluşlar ve Diğer" olmak üzere 5 alt kategori içermektedir.

- Haber Kaynağı Olarak Kurumun Türü: Kategori, "Yükseköğretim Kurumları, Türkiye Kamu Kurumları, Yurtdışı Kamu Kurumları, STK'lar/ Organizasyonlar vb., Şirketler, Kurum Bilgisi Bulunmayanlar ve Diğer" olmak üzere 7 alt kategoriye sahiptir.

- Yükseköğretim Kurumlarıyla Bağlantı: Bu kategori bilim haberlerinin yükseköğretim kurumlarıyla bağlantısını tespit edebilmek için özellikle oluşturulmuştur. Kategori kendi içinde Yükseköğretim Kurumları (Türkiye Devlet), Yükseköğretim Kurumları (Türkiye Vakıf), Yurtdışı Yükseköğretim Kurumları olmak üzere 3 alt kategori barındırmaktadır.

\section{Bulgular}

\section{Basında Bilim Haberlerinin Görünümü}

Örnekleme dâhil edilen gazetelerin her birisinin 20 Ocak, 27 Ocak ve 3 Şubat 2018 tarihli üçer nüshasındaki haberler sayılmış ve çıkan rakam 3'e bölünerek 15 ile çarpılmıştır [(20 Ocak +27 Ocak +3 Şubat)/3x15]. Böylece her bir gazetenin örneklem sürecinde yayınladığı toplam haber sayısı hesaplanmaya çalışılmıştır. Bu hesaplamaya göre Cumhuriyet'te 1215, Hürriyet'te 1005, Milliyet'te 1375, Sabah'ta 835, Sözcü'de ise 1155 olmak üzere, köşe yazıları, reklam nitelikli haberler ve spor sayfaları hariç toplam 5585 rakamına ulaşılmıştır.

Analiz sonucunda bilimsel niteliğe sahip 291 haber tespit edilmiştir. Bu haberlerin 72'si Cumhuriyet'e, 68'i Milliyet'e, 62'si Sözcü'ye, 46'sı Hürriyet'e, 43'ü ise Sabah'a aittir. Bu bilgiler ışığında bilim haberlerinin (291), 5 gazetedeki toplam habere (5585) göre oranı \% 5,21'dir. Bu oran birçok ülke medyasıyla paralellik göstermektedir. Dimopoulos ve Koulaidis'un (2002, s. 229) verdiği bilgilere göre, bilim ve teknoloji haberlerinin oranı Yunan medyasında \% 1,5-2,5 (2002), İngilte- 
re medyasında \% 5 (1995), ABD medyasında yaklaşık \% 2 (1997) iken Avustralya medyasında \% 2,9'dur (1995). Bizim çalışmamızın, sıralanan ülkelerdeki çalışmaların en yakın tarihlisinden yaklaşık 15 yıl sonra yapıldığını; araştırmamızda köşe yazılarının ve spor sayfalarının örneklem dışı tutulduğunu dikkate aldığımızda çıkan oranın düşük olduğu söylenebilir.

Bilim haberleri, gazeteler özelinde dağıldığında Grafik 1'deki rakamlar ortaya çıkmaktadır. Bu kategoride toplamda en yüksek oran Cumhuriyet $(\% 5,93)$ gazetesindedir. Oran Sözcü'de \% 5,37, Sabah'ta 5,15, Milliyet'te \% 4,95 iken, \% 4,58 ile Hürriyet sonuncu sırada yer almaktadır. Gazeteler arasındaki farklııklar anlamlı düzeyde değildir.

Grafik 1. Bilim haberinin gazetelere göre dağılımı/oranı

\begin{tabular}{|c|c|c|c|c|c|}
\hline \multicolumn{6}{|l|}{1600} \\
\hline \multicolumn{6}{|l|}{1400} \\
\hline \multicolumn{6}{|l|}{1200} \\
\hline \multicolumn{6}{|l|}{1000} \\
\hline \multicolumn{6}{|l|}{800} \\
\hline \multicolumn{6}{|l|}{600} \\
\hline \multicolumn{6}{|l|}{400} \\
\hline \multicolumn{6}{|l|}{200} \\
\hline 0 & Cumhuriyet & Hürriyet & Milliyet & Sabah & Sözcü \\
\hline 口 Örneklemdeki Bilim Haberi Sayısı & 72 & 46 & 68 & 43 & 62 \\
\hline ص Örneklemdeki Ortalama Haber Sayısı & 1215 & 1005 & 1375 & 835 & 1155 \\
\hline $\begin{array}{l}\text { Bilim Haberlerinin Gazetelerin Kendi } \\
\text { Haberlerine Oranı }\end{array}$ & 5,93 & 4,58 & 4,95 & 5,15 & 5,37 \\
\hline
\end{tabular}

\section{Bilim Haberlerinin Bilim Dallarına Göre Dağılımı}

Örneklem aralı̆ıında bilim haberi niteliği taşıyan haberlerin, gazetelerin toplam haberlerine göre ( 5585 habere göre) bilim dallarına dağıımı Grafik 2' deki gibidir. Grafiği incelemeden önce bir hususa değinmek gerekmektedir. Bilimsel nitelikli haberler, içeriğinden ya da disiplinlerarasılığından dolayı birden fazla bilim dalına kodlanabilmiştir. Örneğin teknoloji aracılığıyla geliştirilen protez, tıp/sağlık alanında kullanılacağından bu haber hem teknoloji hem de tıp/sağlık alanına kodlanmışıı. Bu nedenle bilim dallarına dağııılan haberlerin toplamı, toplam bilim haberi sayısından fazla olabilmektedir.

Bilim haberlerinin bilim dallarını gösteren Grafik 2 incelendiğinde Tıp/Sağlık kategorisinin \% 2,17 ile en yüksek kategori olduğu anlaşılmaktadır. Bu kategoriyi ikinci sırada \% 0,77 ile Doğa/Çevre takip ederken, üçüncü sırayı \% 0,57'lik oranla teknoloji haberleri izlemektedir. Diğer oranlar ise \% 0 ila 0,45 aralığında değişmektedir. Oranlar genel olarak çok düşüktür ve hatta bazı kategoriler yokluk düzeyindedir. Sayıca belirtecek olursak en fazla haber 121 rakamıyla Tıp/Sağlık 
kategorisindedir. Doğa/Çevre 43; Teknoloji 32; Eğitim 25; Tarih/Arkeoloji 15; Psikoloji 15; Ekonomi 14, Kültür/Yaşam 12; Siyaset 9; Sanat 4; Hukuki Meseleler 3; Edebiyat 2; Felsefe ise 1'dir. Matematik, Fizik, Kimya ile ilgili bilim haberine rastlanmamıştır. Bilimsel nitelikli haberleri gazeteler özelinde dağıtığımızda, hiçbir veri \% 3'ün üzerine çıkmamakta, veriler Grafik 2'dekiyle benzerlik göstermektedir. Bu nedenle bu kategori gazeteler özelinde grafiğe dönüştürülmemiştir.

Grafik 2. Bilim haberlerinin tüm haberler içindeki oranı

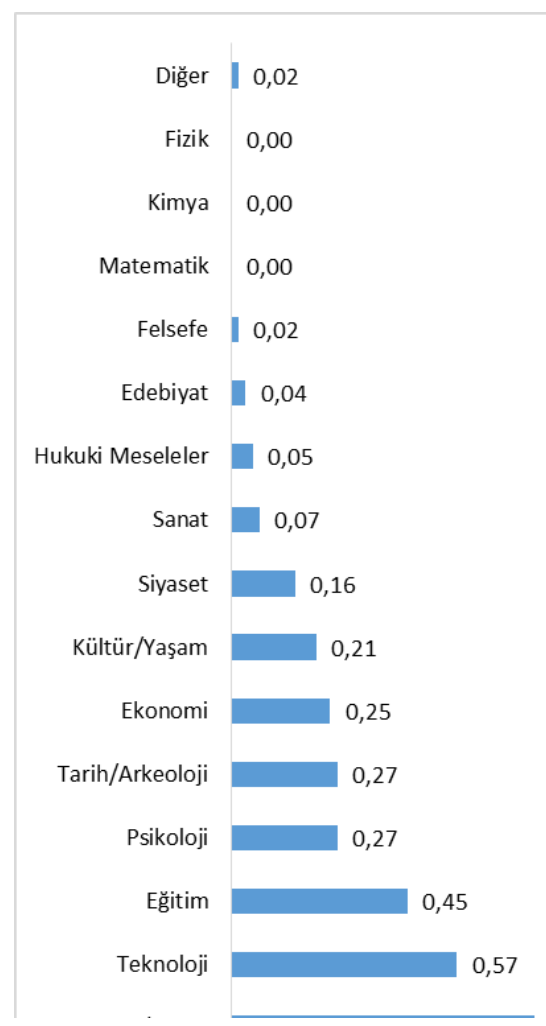

Bilim haberleri, bilim kategorilerine göre kendi aralarında dağıtııdığında Grafik 3'e ulaşılmaktadır. Grafik 3 incelendiğinde Tıp/Sağlık kategorisinin \% 41,58'lik bir oranla ilk sırada yer aldığı görülmektedir. Bu oran, bilim haberlerinin yaklaşık yarısına denk gelmektedir. İkinci sırada \% 14,78 ile Doğa/Çevre, üçüncü sırada \% 11 ile Teknoloji, dördüncü sırada ise \% 8,59 ile Eğitim kategorisi yer almaktadır. Diğer kategorilerin oranları \% 5,15 ile 0 aralığında değişmektedir. Grafik, yazıı basının daha çok tıp/sağlık, doğa, teknoloji gibi alanlarda bilim haberlerine eğilimli olduğunu ortaya koymaktadır. Çalışmamızın kuramsal kısmındaki bilgiler göz önünde bulundurulduğunda, bilim gazeteciliği açısından Türkiye basınının diğer ülkelerle paralelliğe sahip olduğu söylenebilir. 
Grafik 3. Haberlerin bilim dallarına göre kendi aralarında dağıımı

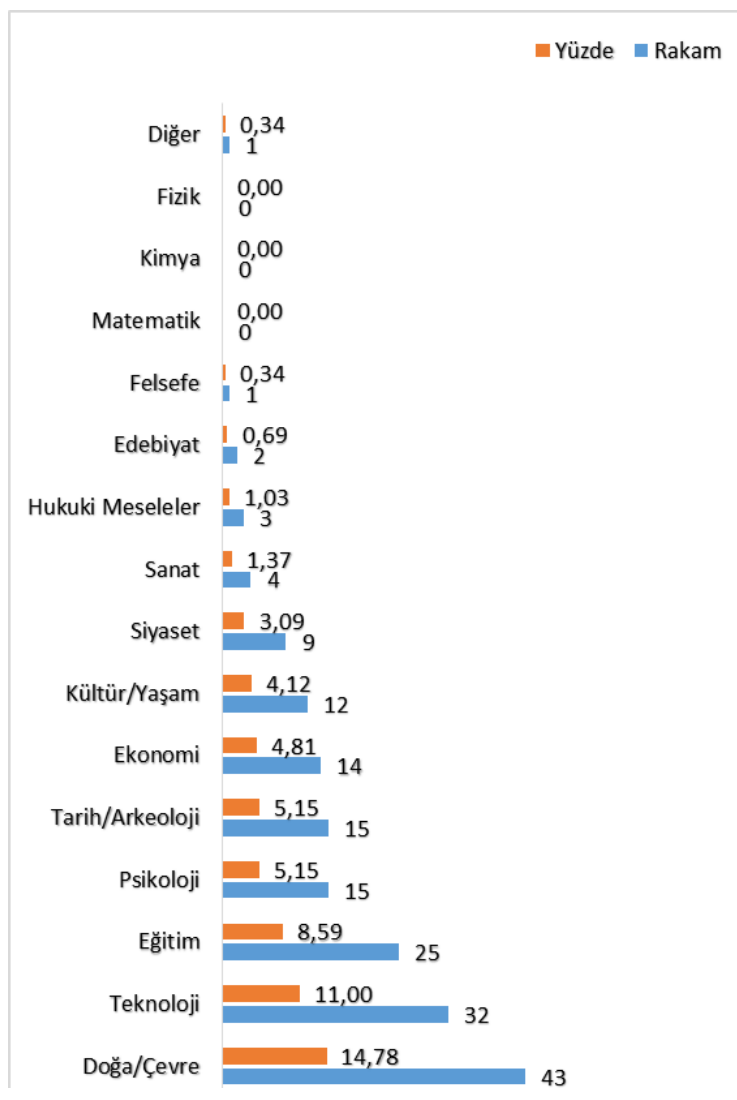

Bilim haberlerinin, bilim dallarına ve gazetelere göre dağılımı hesaplandığında Grafik 4'e ulaşılmaktadır. Grafikte tıp/sağlık, doğa, teknoloji gibi bilim alanlarının, bilim haberlerini egemenliğine aldığı görülmektedir. Grafikte en yüksek oran \% 54,85 ile Sözcü gazetesinin Tıp/Sağlık kategorisindedir. Sözcü'nün bilim haberlerinin yarısından fazlası tıp ve sağlıkla ilgilidir. Bu kategoride ikinci sırada \% 46,51 ile Sabah gazetesi yer almaktadır. Sabah'ın haberlerinin yarısına yakını yine tıp ve sağlık alanından gelmektedir. Üçüncü sırada Hürriyet $(\% 39,13)$, dördüncü sırada Milliyet $(\% 38,24)$ yer alırken beşinci sırada Cumhuriyet $(\% 31,94)$ bulunmaktadır. Grafiğin ikinci yüksek oranı Doğa/Çevre kategorisindedir. Bu kategoride Cumhuriyet gazetesi \% 19,44'lük bir oranla ilk sırada yer alırken, ikinci sırada \% 17,65 ile Milliyet, üçüncü sırada \% 15,22 ile Hürriyet, dördüncü sırada \% 11,63 ile Sabah yer alırken son sırada \% 8,06'ık oranıyla Sözcü bulunmaktadır. Bu grafikte üçüncü yüksek oranlar Teknoloji kategorisindedir. Teknoloji kategorisinde birincilik \% 20,93 ile Sabah gazetesine aittir. İkinci sırada \% 13,24 ile Milliyet, üçüncü sırada $\%$ 10,87 ile Hürriyet, dördüncü sırada \% 8,06 ile Sözcü, son sırada ise \%5,56 ile Cumhuriyet yer almaktadır. Eğitim içerikli bilim haberleri Hürriyet'te \% 19,57'lik 
bir orana sahiptir ve belirgindir. Bu kategoride Cumhuriyet ve Milliyet'in oranları \% 8 civarındadır. Kategoride Sabah \% 4,65 ile dördüncü iken, Sözcü de \% 3,23 ile beşincidir. Psikoloji ve Tarih/Arkeoloji kategorilerinde oranlar birbirlerine yakındır. Bu kategorilerdeki en yüksek oran Milliyet'in Psikoloji kategorisindedir (\% 7,35), en düşük oran \% 0 ile Sabah gazetesinin Psikoloji kategorisindedir. Diğer oranlar Grafik 4'te görüldügü gibidir. Grafik 2, 3 ve 4'teki veriler, bilim haberciliği ile sağlık haberciliğinin yöndeş alanlar olduğunu göstermektedir.

Grafik 4. Bilim haberlerinin bilim dalları bazında gazetelere göre dağılımı

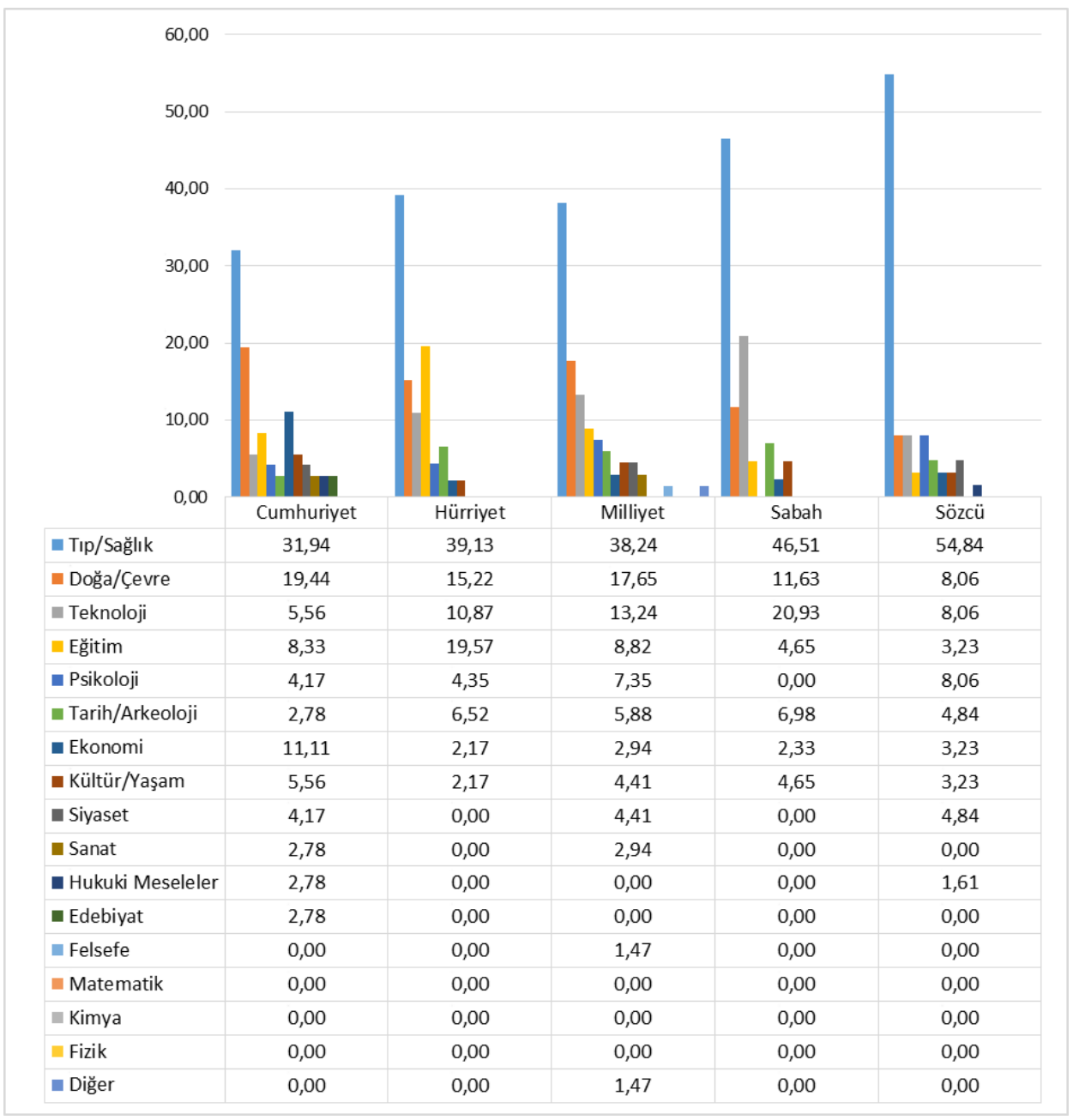




\section{Bilim Haberlerinin Bilimsel Kaynağı}

Gazetelerdeki bilimsel nitelikli haber sayıları ve içerikleri kadar, bu haberlerin kaynağı da önem taşımaktadır. Araştırmamızda gazetelerin hangi kaynakları kullanarak bilim haberi ürettiğine göz atıldığında Bireysel Açıklama kategorisinin ön plana çıktığı görülmektedir. Grafik 5 incelendiğinde bilimsel nitelikli haberlerin \% 34,71'inin (101 haber), uzman görüşü olarak da nitelendirebileceğimiz Bireysel Açıklamalara dayandığı görülmektedir. Yunanistan'da yapılan araştırmada tekno-bilim haberlerinin \% 40'ının gazeteciler tarafından oluşturulduğunu, bu haberlerin \% 26,7'sinin ise uzman görüşlerine dayandığını göstermiştir (Dimopoulos and Koulaidis, 2002, s. 230). Çalışmamızı betimlemeye devam edecek olursak Araştırma ifadesini kullanan haber oranının \% 19,93 (58 haber) olduğu görülecektir. Bu oranı 42 haberle, yani \% 14,43 ile Proje/Program kategorisi takip etmektedir. Diğer oranlar grafikte görüldügü gibidir. Bu sonuçlar, Erdoğan'ın (2007, s. 208) araştırmasındaki sonuçlarla paralellik göstermektedir. Erdoğan, yerel basında üniversite hocalarının ve uzmanların, yaygın basında ise tıp doktorlarının bilim haberlerine büyük oranda kaynaklık ettiğini ortaya koymuştur.

Grafik 5. Haberin bilimsel kaynağı

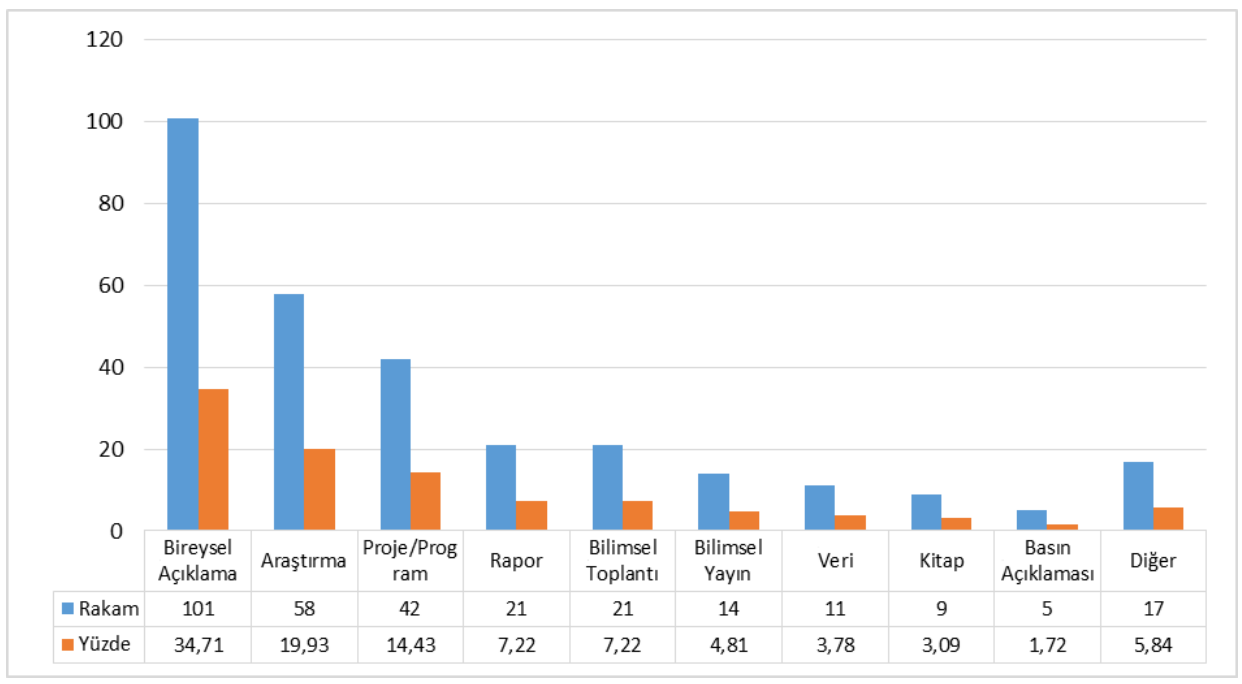

Bilimsel nitelikli haberleri, haberin bilimsel kaynağına ve gazetelere göre dağıtıığımızda Grafik 6'daki veriler ortaya çıkmaktadır. Bu kategorideki rakamlar \% 0'lık oranla Sözcü'nün Basın Açıklaması kategorisi ile \% 43,48 oranla Hürriyet'in Bireysel Açıklama kategorisi arasında değişiklik göstermektedir. Bireysel Açıklama kategorisindeki oranlar sırasıyla Sabah \% 41,86, Milliyet \%35,29, Sözcü $\%$ 32,26, Cumhuriyet \% 26,39 şeklindedir. Araştırmalardan en çok yararlanan gazete \% 32,26 ile Sözcü gazetesidir. İkinci sırada \% 25,58 ile Sabah, üçüncü sırada \% 15,28 ile Cumhuriyet, dördüncü sırada \% 14,71 ile Milliyet yer alırken, 
Hürriyet'in oranı \% 13,04'tür. Proje/programları haber kaynağı olarak en çok gösteren gazete \% 17,65 ile Milliyet gazetesidir. Bu kategoride ikinci sırada 16,67 ile Cumhuriyet gazetesi, üçüncü sırada 13,95 ile Sabah gazetesi, dördüncü sırada \% 13,04 ile Hürriyet gazetesi yer alırken, son sırada Sözcü bulunmaktadır ve oranı \% 9,68'dir. Raporları bilim haberlerine en fazla kaynak gösteren gazete \% 12,50 ile Cumhuriyet'tir. Bilimsel Toplantı kategorisi incelendiğinde ilk sırada \% 11,76 ile Milliyet; ikinci sırada \% 11,11 ile Cumhuriyet'in yer aldığı anlaşılmaktadır. Bilimsel yayınlardan en çok yararlanan iki gazete Sabah ve Cumhuriyet'tir (sırasıyla $\% 6,98$ ve \% 6,94). Veri ve kitabı bilimsel kaynak olarak en fazla gösteren gazete Sözcü'dür (her iki oran da \% 6,45'tir). Basın açıklamalarında en fazla yararlanan gazete Sabah'tır $(\%$ 4,65). Bilimsel araştırmaların en önemli kaynakları olan bilimsel yayınların ve kitapların, düşük oranda bilim haberlerine kaynaklık ettiği görülmektedir. Bu kategori, bilim muhabirlerinin, bilimsel yayınları yeterli ölçüde kaynak olarak kullanmadığını göstermektedir.

Grafik 6. Haberin bilimsel kaynağının gazetelere göre dağılımı

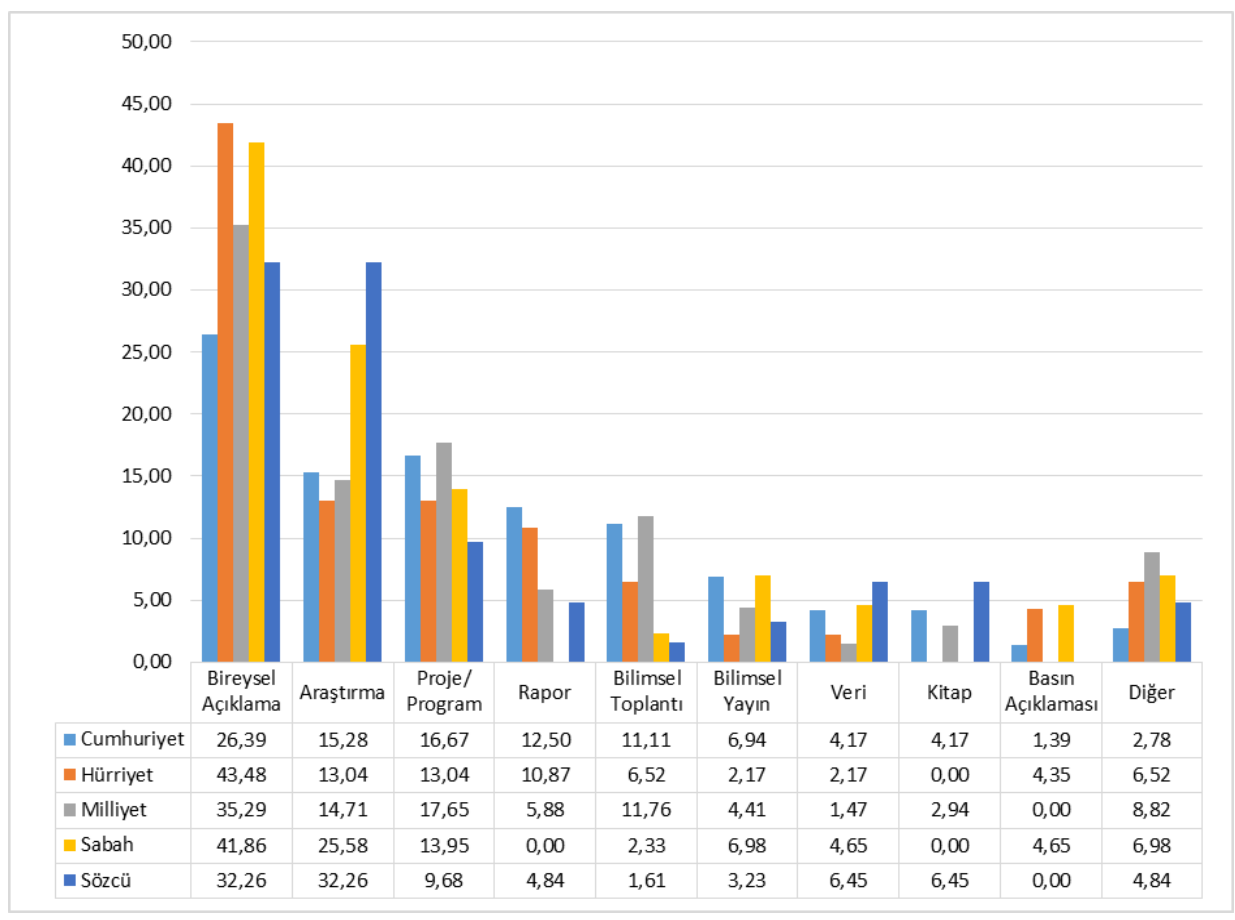

\section{Bilim Haberlerinin Kurumsal Kaynağının Statüsü/Niteliği}

Bilim çeşitli kurumlar tarafından üretilebilmektedir. Her kurum kendi ilgisi, siyasi duruşu, iktisadi konumu, bulunduğu sosyo-kültürel çevresi gibi çeşitli etmenler doğrultusunda bilimsel çalışmalar yapabilmekte/yaptırabilmektedir. Her 
bilimsel çalışma da belirli bir epistemolojiden hareket etmekte ve buna göre araştırma yöntemini belirlemektedir. Bu nedenle çalışmaların yapıldığı çevreler ve bu araștırmaları kamusallaștıran yayınlar önem arz etmektedir (Bauer vd., 2000, s. 31-32). Bu gibi etmenler düşünüldügünnden haberlerin bilim dalları kadar, kurumun statüsü ve türü de önemlidir. Bu kategori gazetelerin hangi statüdeki kurumların yapmış olduğu bilimsel çalışmalara referansta bulunduğunu tespit etmeye yöneliktir. Bu başlık altında temel olarak 4 kategori belirlenmiştir. Türkiye'deki kamu kurumları, Türkiye'deki kamu dışı kurumlar, yurtdışındaki kamu veya kamu dışı kurumlar ve bir de uluslararası niteliğe sahip kurumlar şeklinde kategorik ayrıma gidilmiştir. Diğer kategorilerde olduğu gibi bazı haberler birden fazla statülü kurumu bilimsel nitelikli haberlerinde kaynak olarak gösterebilmiştir.

Bilimsel nitelikli haberleri, kurumsal kaynağın statüsüne göre dağıttığımızda Grafik 7'deki veriler ortaya çıkmaktadır. Grafik 7 incelendiğinde haberlere en fazla kaynaklık eden kurumlar Türkiye'deki kamu dışı kurumlar olduğu görülmektedir. Oran bu kategoride \% 32,65'tir. İkinci sırayı Yurtdışı Kamu/Kamu Dışı Kurumlar kategorisi \% 30,24 ile takip etmektedir. Üçüncü sırayı Türkiye Kamu Kurumları \% 26,12 'lik bir oranla izlemektedir. Uluslararası statüye sahip kurum ve kuruluşlara referansta bulunan haber oranı \% 2,41'dir.

Grafik 7. Bilim haberlerinin kaynağının kurumsal statüsü/niteliği

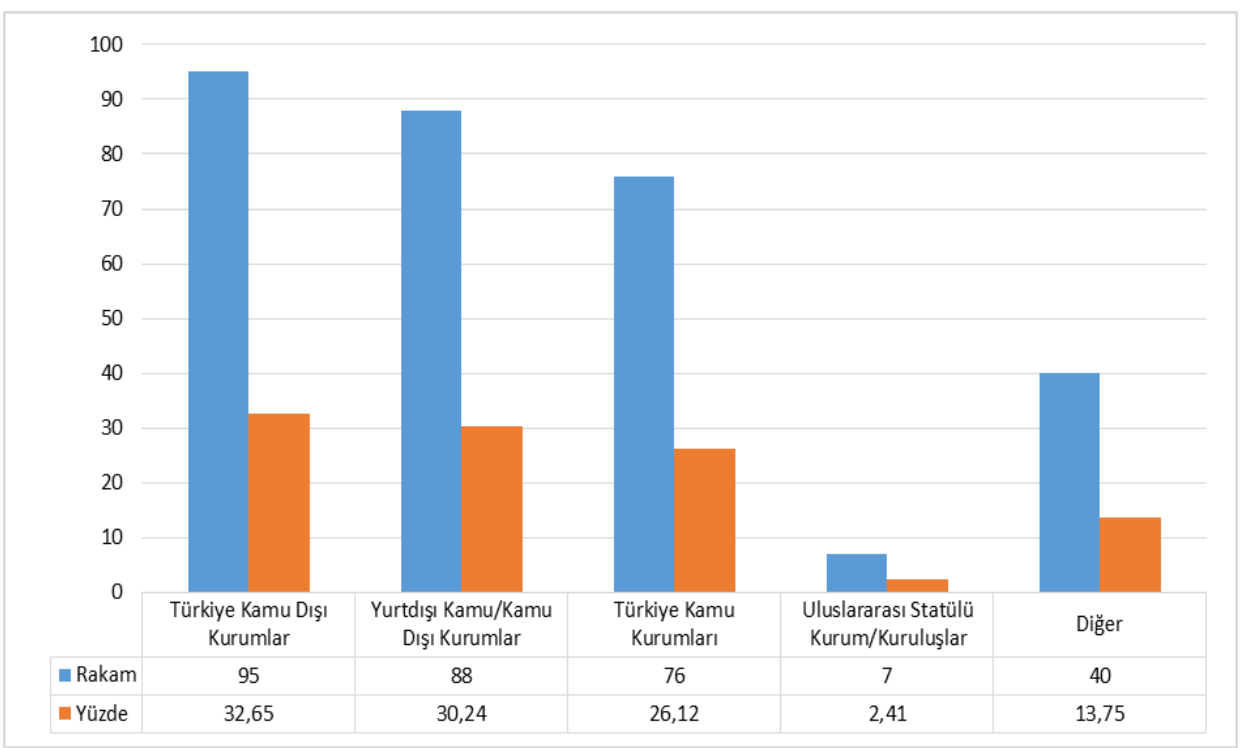

Bilim Haberlerinin Kaynağının Kurumsal Statüsü/Niteliği ana kategorisinin alt kategorileri, gazeteler özelinde Grafik 8'deki gibidir. Grafik 8 incelendiğinde, en yüksek oran, \% 53,49 ile Sabah gazetesinin Yurtdışı Kamu/Kamu Dışı Kurumlar kategorisinde karşımıza çıkmaktadır. Bu kategoride ikinci en yüksek oran, yine 
Sözcü'ye aittir (\% 48,39). Hürriyet'in oranı \% 26,09, Cumhuriyet'in oranı \% 20,83, Milliyet'in oranı ise \% 11,76 'dır. Türkiye'deki kamu dışı kurumları en fazla kaynak olarak kullanan gazete \% 45,59 ile Milliyet; en az kullanan \% 19,35 ile Sözcü gazetesidir. Bu kategoride Cumhuriyet'in oranı da yüksektir (\% 41,67). Türkiye'deki kamu kurumlarını kaynak olarak en fazla gösteren gazete \% 44,12 ile Milliyet'tir. Bu kategoride Hürriyet \% 30,43 ile ikinci sırada yer alırken, Cumhuriyet \% 22,22 ile üçüncü sırada bulunmaktadır. Sabah dördüncü (\% 18,6), Sözcü ise sonuncudur (\% 12,90). Uluslararası kurum/kuruluşları Milliyet ve Sabah gazeteleri hiç kaynak olarak kullanmamıştır. Kurumu belirtilmeyen ya da bu kategorilere girmeyen diğer veriler Grafik 8'de görülmektedir.

Grafik 8. Bilim haberlerinin kaynağının kurumsal statüsü/niteliğinin gazetelere göre dağlımı

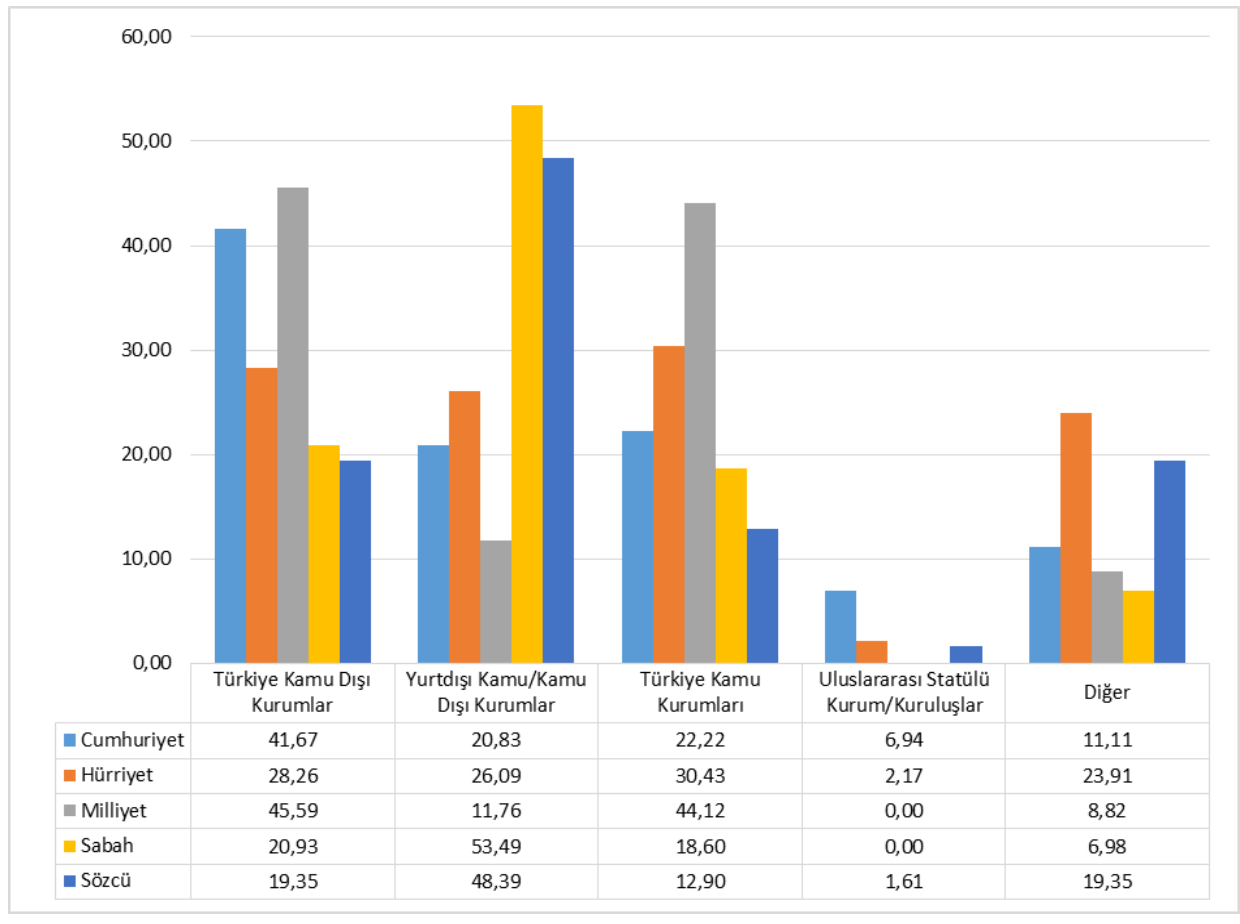

\section{Haber Kaynağı Olarak Kurumun Türü}

Bu kategori bir önceki kategoriyle aşağı yukarı benzeri niteliklere sahiptir. Ancak bilimsel nitelikli haberlerin, hangi tür kurumlarca üretilen bilgilerden yararlanılarak oluşturulduğunu daha ayrıntılı biçimde anlamak için oluşturulmuştur. Bilimsel nitelikli haberlere kaynaklık eden kurumların STK, organizasyon, şirket, kamu kurumu ya da başta yükseköğretim olmak üzere eğitim kurumlarının olup olmadığı anlam taşımaktadır. Bu, medyanın bilimden ne anladığına ışıklık ede- 
cek ve medya organizasyonlarının hangi tür kurumlarla genellikle ilişkili olduğunu ortaya koyabilecektir. Bu kategoride de yine bir haberin birden fazla kategoriye işaretlenmesinden dolayı, kategorilerin toplamının, toplam haber sayısını geçtiğini belirtmemiz gerekmektedir. Kodlamalar sonucunda oluşan veriler Grafik 9'da görülmektedir. Bu kategori incelendiğinde en yüksek oranın \% 46,39 ile (135 haber) ile Yükseköğretim Kurumları kategorisinde olduğu anlaşımaktadır. İkinci sırada STK/Organizasyonlar vb. kategorisi ile Şirketler kategorisi aynı oranlarla (\% 14,78 ve $43^{\prime}$ er haber) bulunmaktadır. Türkiye'deki kamu kurumları \% 11,68'lik (34 haber) oranla üçüncü; Kurum Bilgisi Bulunmayanlar kategorisi \% 16,15 (47 haber) ile dördüncü sırada yer alırken, yurtdışı kaynaklı kamu kurumlarının oranı $\%$ 2,06'dır (6 haber).

Grafik 9. Bilim haberinin kaynağı olarak kurumun türü

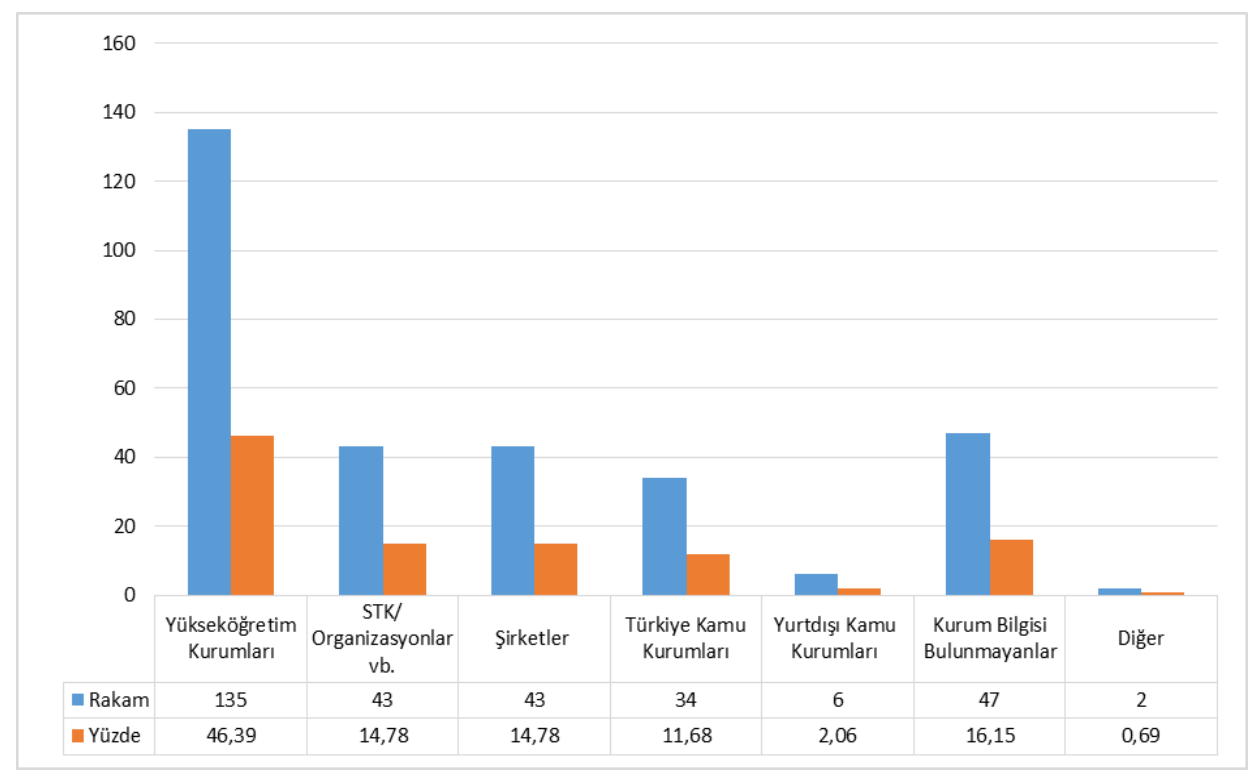

Bilim haberlerinin kaynağı olarak kurumların türü, gazeteler özelinde Grafik 10'daki gibidir. Grafiğe göz atıldığında yığılmanın yükseköğretim kurumlarında gerçekleştiği dikkat çekmektedir. Bu kategorideki bütün oranlar \% 40'ın üzerindedir. Bu da, bilim haberlerinin yaklaşık yarısına üniversitelerin kaynaklık ettiği anlamına gelmektedir. Bu kategorideki en yüksek oran Milliyet gazetesine aittir (\% 55,88). Sabah'ın oranı \% 48,84; Sözcü'nünki \% 45,16; Hürriyet'inki \% 41,30 iken Cumhuriyet'inki \% 40,28' dir. STK'lar ve çeşitli organizasyonları bilim haberlerinde kaynak olarak en fazla gösteren gazete Cumhuriyet'tir $(\% 26,39)$. Oranlar bu kategoride sırasıyla şöyle devam etmektedir: Hürriyet \% 17,39, Milliyet 11,76, Sözcü \% 8,06 ve Sabah \% 6,98. Şirketler kategorisindeki oranlar \% 19,12 ile \% 11,29 arasında değişmektedir. Hiçbir gazetede oran \% 10'un altında değildir. 
Bu, gazetelerin şirketlerle olan ilişkilerini göstermektedir. Türkiye'deki kamu kurumları da bilim haberlerine anlamlı düzeyde kaynaklık etmektedir. Türkiye Kamu Kurumları kategorisi incelendiğinde, Milliyet'in \% 14,71, Cumhuriyet'in \% 13,89, Hürriyet'in \% 10,87, Sözcü'nün \% 9,68, Sabah'ın ise \% 6,98'lik bir orana sahip olduğu anlaşılmaktadır. Yurtdışındaki kamu kurumları bilim haberlerine anlamlı düzeyde kaynaklık etmemektedir. Verilerin yüksek olduğu diğer bir kategori ise Kurum Bilgisi Bulunmayanlar kategorisidir. Bu kategoride Sözcü'nün \% 25,81 gibi yüksek bir orana sahip olduğu görülmektedir. Hakeza Hürriyet'in oranı da \% 21,74'tür. Cumhuriyet'te \% 13,89, Milliyet'te \% 10,29, Sabah'ta ise \% 9,30 gibi bir oran mevcuttur. Bu kategori, bilim haberlerinde kaynak sorununa işaret etmektedir. Bilindiği üzere, haber medyasında kaynak kullanımı ve gösterimi, haberin/bilginin güvenirliği açısından önemlidir. Haberlerin üretildiği kurumlara ilişkin bilgilerin, bilim haberlerinde yer almaması, hem haberciliğe hem de bilime olan güveni sarsabilmektedir.

Grafik 10. Bilim haberinin kaynağı olarak kurumun türünün gazetelere göre dağılımı

\begin{tabular}{|c|c|c|c|c|c|c|c|}
\hline \multicolumn{8}{|l|}{60,00} \\
\hline \multicolumn{8}{|l|}{50,00} \\
\hline \multicolumn{8}{|l|}{40,00} \\
\hline \multicolumn{8}{|l|}{30,00} \\
\hline \multicolumn{8}{|l|}{20,00} \\
\hline \multicolumn{8}{|l|}{10,00} \\
\hline \multirow{2}{*}{0,00} & & & & & $=$ & 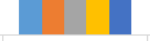 & $=$ \\
\hline & $\begin{array}{l}\text { Yükseköğretim } \\
\text { Kurumları }\end{array}$ & $\begin{array}{c}\text { STK/ } \\
\text { Organizasyonla } \\
\text { r vb. }\end{array}$ & Şirketler & $\begin{array}{l}\text { Türkiye Kamu } \\
\text { Kurumları }\end{array}$ & $\begin{array}{l}\text { Yurtdışı Kamu } \\
\text { Kurumları }\end{array}$ & $\begin{array}{c}\text { Kurum Bilgisi } \\
\text { Bulunmayanlar }\end{array}$ & Diğer \\
\hline - Cumhuriyet & 40,28 & 26,39 & 13,89 & 13,89 & 0,00 & 13,89 & 0,00 \\
\hline würriyet & 41,30 & 17,39 & 13,04 & 10,87 & 0,00 & 21,74 & 0,00 \\
\hline " Milliyet & 55,88 & 11,76 & 19,12 & 14,71 & 1,47 & 10,29 & 1,47 \\
\hline Sabah & 48,84 & 6,98 & 16,28 & 6,98 & 9,30 & 9,30 & 2,33 \\
\hline = Sözcü & 45,16 & 8,06 & 11,29 & 9,68 & 1,61 & 25,81 & 0,00 \\
\hline
\end{tabular}

\section{Yükseköğretim Kurumlarıyla Bağlantılar}

Bilim haberlerinin kaynaklarını yükseköğretim kurumları kategorisinde sorguladığımızda Grafik 11'deki sonuçlara ulaşılmaktadır. Bir haber birden fazla öğretim kurumuyla bağlantılı olabilmektedir. Örneğin bir konu hakkında hem devlet üniversitesindeki hem de vakıf üniversitesindeki öğretim elemanlarından görüş alındığı, ya da kamu ve vakıf üniversitesi işbirlikleriyle yapılan çalışmalardan haberlerin üretildiği durumlarla karşılaşılmıştır. Bu gibi durumlarda bir haber hem 
kamu hem de vakıf üniversitesi kategorisine kodlanmıştır. Ayrıca yurtdışındaki üniversitelerin statülerinin farklılıklar göstermesinden dolayı, yurtdışı üniversiteleri kamu ve vakıf şeklinde ayrılmayarak tek kategori olarak tasarlanmıştır. Bu etmenler doğrultusunda yapılan analiz sonucunda 135 haberin üniversitelerle bir şekilde bağlantılı olduğu tespit edilmiştir. Veriler Grafik 11'deki gibidir. Grafik incelendiğinde yükseköğretim kurumlarıyla bağlantıların, üç kategori bağlamında \% 14,09 ile \% 16,84 arasında değişiklik gösterdiği görülmektedir. Bilimsel nitelikli haberin 49'u $(\%$ 16,84) yurtdışındaki yükseköğretim kurumlarıyla; 47'si $(\% 16,15)$ Türkiye'deki kamu üniversiteleriyle; 41 'i $(\% 14,09)$ ise Türkiye'deki vakıf üniversiteleriyle bağlantıı olduğu anlaşılmaktadır.

Grafik 11. Bilim haberlerinin yükseköğretim kurumlarıyla bağlantısı

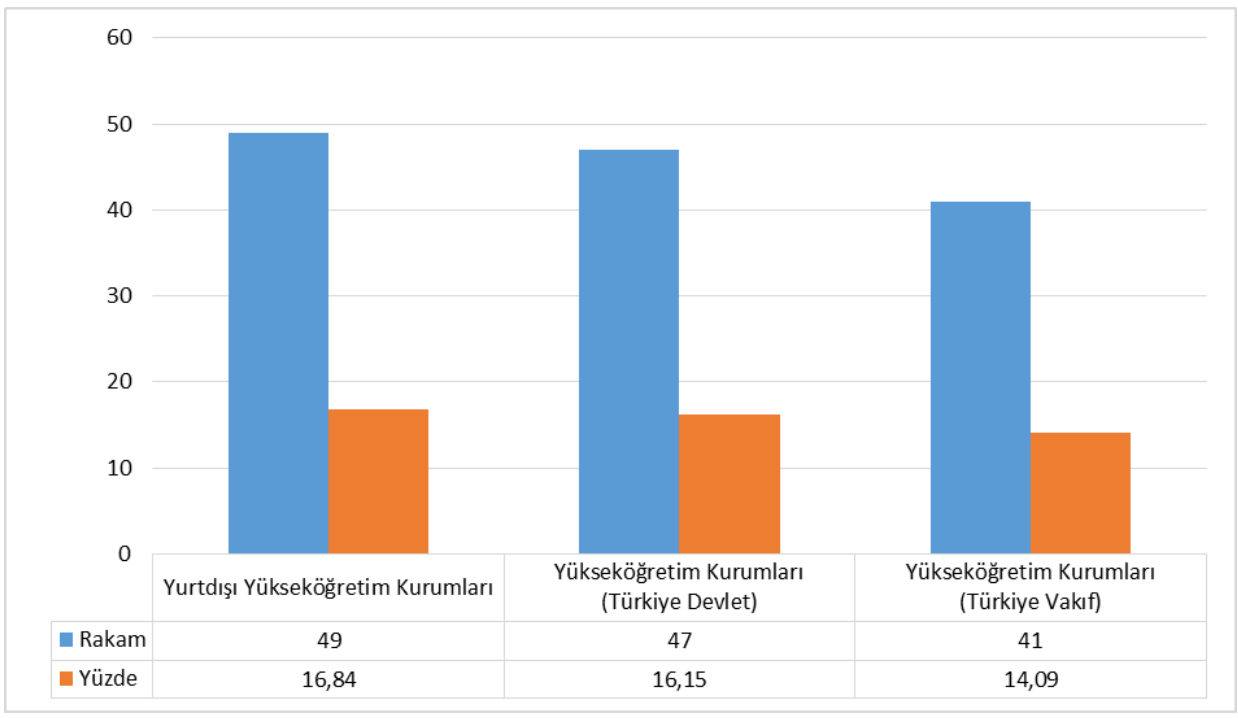

Bilimsel nitelikli haberlerin yükseköğretim kurumlarıyla bağlantısını gazeteler özelinde sorguladığımızda Grafik 12'deki sonuçlara ulaşılmaktadır. En yüksek oranın Yükseköğretim Kurumları (Türkiye Devlet) kategorisinde \% 33,82'lik bir oranla Milliyet'te olduğu anlaşılmaktadır. İkinci en yüksek kategori Sözcü'nün Yurtdışı Yükseköğretim Kurumları $(\% 32,26)$ kategorisiyken, üçüncü sırayı Sabah'ın aynı kategorisi takip etmektedir (\% 30,12). Milliyet'in Yükseköğretim Kurumları (Türkiye Vakıf) kategorisindeki oranı, yine dikkat çekmektedir (\% 25). Grafikte Milliyet'in yurtdışındaki üniversitelerle bağlantısının yokluk düzeyinde olduğu görülmektedir (\% 0). Grafik incelendiğinde Sözcü'nün Türkiye'deki yükseköğretim kurumlarıyla bağlantısının düşük olduğu anlaşılmaktadır $(\% 3,23)$. Aynı durum Sabah gazetesinin Türkiye'deki vakıf üniversiteleriyle ilişkileri için de söylenebilir $(\%$ 6,98). 
Grafik 12. Bilim haberlerinin yükseköğretim kurumlarıyla bağlantısının gazetelere göre dağıııı

\begin{tabular}{|c|c|c|c|c|c|c|}
\hline \multicolumn{7}{|c|}{40,00} \\
\hline \multicolumn{7}{|c|}{35,00} \\
\hline \multicolumn{7}{|c|}{30,00} \\
\hline \multicolumn{7}{|c|}{25,00} \\
\hline \multicolumn{7}{|c|}{20,00} \\
\hline \multicolumn{7}{|c|}{15,00} \\
\hline \multicolumn{7}{|c|}{10,00} \\
\hline \multicolumn{7}{|c|}{5,00} \\
\hline \multicolumn{2}{|r|}{0,00} & Cumhuriyet & Hürriyet & Milliyet & Sabah & Sözcü \\
\hline — Yurtdışı Yükseköğretim Kur & umları & 12,50 & 15,22 & 0,00 & 30,23 & 32,26 \\
\hline $\begin{array}{c}\text { Yükseköğretim Kurumları } \\
\text { (Türkiye Devlet) }\end{array}$ & & 12,50 & 17,39 & 33,82 & 11,63 & 3,23 \\
\hline $\begin{array}{c}\text { Yükseköğretim Kurumları } \\
\text { (Türkiye Vakıf) }\end{array}$ & & 15,28 & 8,70 & 25,00 & 6,98 & 9,68 \\
\hline
\end{tabular}

\section{Değerlendirme ve Sonuç}

Bilimsel bilginin üretimi ve dağıtımı iktisadi ve siyasi/yönetimsel mekanizmalardan bağımsız değildir. Her çalışma bir bakış açısı, bir dünya görüşü barındırmakta ve yaşamın bir alanını ya aydınlatmakta ya da mevcut sorunu tespit ederek çözüm üretmeye çalışmaktadır. Bilimsel bilginin üretilmesi kadar uygulamalı ya da kuramsal biçimde kamusallaştıııabilmesi de önem taşımaktadır. Çalışmamız, bilimsel bilginin basın yoluyla hangi alanlarda ve ne düzeyde kamusallaştııılı̆̆ını analiz etmiştir. Analizimiz, Türkiye basınında bilim içerikli haberlerin oransal olarak yetersiz olduğunu ve yığılmanın belirli bilim alanlarında gerçekleştiğini göstermiştir.

Çalışmamızda bilim haberlerinin, tüm haberler içerisindeki oranının \% 5 civarında kaldığı sonucuna ulaşılmıştır. Bilim haberlerinin, bilim dallarına göre dağılımında en yüksek oranların sağlık/tıp bilimleri, doğa bilimleri, teknoloji bilimleri gibi pozitif bilimler alanına ait olduğu tespit edilmiştir. Akademiler ve bilimsel yapılanmalar tarafından yayınlanan bilimsel dergilere başvuru oranı çok düşüktür. Bu dergiler, bilim haberlerine anlamlı düzeyde kaynaklık etmemektedir. Bilim alanlarında uzman kişilerden -genel olarak üniversite öğretim elemanlarının- alınan görüşlerle büyük oranda bilim haberlerinin oluşturulduğu sonucuna ulaşılmıştır. Bilim haberlerinin yarıya yakınının üniversitelerle bağlantıı olduğu, yurtdışındaki üniversitelerin de anlamlı düzeyde Türkiye basınındaki bilim haberlerine kaynaklık ettiği anlaşımıştır. Bilim haberinin kurumsal kaynağının belirlenemediği haber oranı da anlamlı düzeydedir. Ayrıca sivil toplum kuruluşları, organizasyonlar gibi oluşumlar ile şirketlerin de bilim haberlerine belirgin biçimde kaynaklık ettiği göz- 
lemlenmiştir. Analizimiz Türkiye'deki bilim gazeteciliğinin, Yunanistan (Dimopoulos ve Koulaidis, 2002), Hollanda (Hijmans vd., 2003), Almanya (Elmar vd., 2008), Italya (Bucchi ve Mazzolini, 2007) gibi ülkelerdeki bilim gazeteciliğiyle benzerlikler taşıdığını ortaya koymuştur. Fakat diğer ülkelerde bu konuyla ilgili yapılan çalışmaların en erken tarihlisinin, bizim çalışmamızdan en az 10 yı önce yapıldığını da göz önünde tutmak gerekmektedir.

Bilimsel çalışmaların yapıldığı ve kamusallaştığı dönemin özelliği, dikkat edilmesi gereken bir noktadır. İçinde bulunduğumuz yaşam koşullarında bilim ve medya alanının baskı altında olduğunu, bu nedenle de hem bilgi üretiminin hem de üretilen bilgiyi kamusallaştırmanın getirilerinden çok götürülerinin olduğu aşikârdır. Kapitalizmle yoğrulmuş medya organizasyonlarının bazı beklentilerini karşılayabilecek şekilde yayın politikaları oluşturması, bilim gazeteciliğinde kurumsallaşma sorunları yaratmaktadır. Ayrıca genel kamusal alana hitap edebilme çabası, medyanın bilime ilişkin bakış açısını ve böylece de kamusal alanın bilime bakış açısını şekillendirmektedir. Şöyle ki medyanın bilim haberciliği bağlamında içeriğine taşıdığı alanlar, kamuda bilimin sadece o alanlardan ibaret olduğu gibi bir düşünce yaratabilmektedir. Oluşan bu bakış açısı ise bilimsel teamüllerden uzaktır. Araştırmamızda çıkan sonuçlara bakıldığında popülerliği yüksek bilim alanlarının bilim gazeteciliğini şekillendirdiği görülmektedir. Bu da iletişim ve medya alanın da içinde bulunduğu sosyal bilimler alanına ilişkin rasyonel bilgilerin kamusallaşamadığı anlamına gelmektedir. Sonuç olarak Türkiye'deki bilim gazeteciliğinin tıp/doğa/teknoloji eksenli bir yapılanma yolunda ilerlediği anlaşılımıştır. Kamusal alanda demokratik süreçleri destekleyecek ve kamusal alanı eşitlikler/haklar düzleminde kurumsallaştırmaya çalışacak toplum bilimsel araştırmalar medya aracılığıyla yeterli düzeyde kamuyla paylaşılamamaktadır. Sosyal bilimler alanında yapılan çalışmalar kamusal alanla yeterince iletişim kuramamaktadır.

\section{Kaynaklar}

Alda, A. (2010). In Your Own Voice. Science and the Media. (Ed.) Donald Kennedy and Geneva Overholser. Cambridge: American Academy of Arts and Sciences: 10-12.

Allen, S. (2011). Introduction: Science journalism in a digital age. Journalism,. 2011: 12, Sage: 771-777.

Angler, M. W. (2017). Science Journalism / An Introduction. London and New York: Routledge, Taylor and Francis Group.

Ashwell, D.J. (2014). The challenges of science journalism: The perspectives of scientists, science communication advisors and journalists from New Zealand. Public Understanding of Science. 11. Sage: 1-15.

Bağlama, S. H. (2018). The Resurrection of the Spectre: A Marxist Analysis of Race, Class and Alienation in the Post-War British Novel. Berlin: Peter Lang. 
Baram, M. S. (1971). Social Control of Science and Technology. Science. Vol 172- 3983: 535-539.

Bauer, W. M.; Gregory, J. (2007). From journalism to corporate communication in post-war Britain. Journalism, Science and Society. (Ed.) Martin W. Bauer and Massimiano Bucchi. New York: Routledge, Taylor \& Francis Group: 33-51.

Bauer, W. M.; Howard, S.; Ramos, R.; Yulye, J.; Massarani, L.; Amorim, L. (2013). Global science journalism report: working conditions \& practices, professional ethos and future expectations. Science and Development Network. London: UK.

Bauer, W. M.; Petkova, K.; Boyadjieva, P. (2000). Public Knowledge of and Attitudes to Science: Alternative Measures That May End the "Science War". Bulgarian Academy of Sciences, Science, Technology, \& Human Values, Vol. 25-1: 30-51

Ben-David, J. (1971). The Scientist's Role in Society: A Comparative Study. UK: Englewood Cliffs, N.J., Prentice-Hall.

Bodmer, W. (1985). The Public Understanding of Science. London: The Royal Society.

Brauchli, M.; Eilperin, J. (2009). Science journalism: From the newsroom. The Washington Post: 25 Haziran.

Brito, A. C.; Saraiva, S.; de Lima, R.F. (2012). The Role of Science in Society: Challenges in a Time of Global Changes. Journal of Ecosystem \& Ecography. Vol 2-5: 1-6.

Bucchi, M.; Mazzolini, R. G. (2007). Big science, little news / Science coverage in the Italian daily press, Journalism, Science and Society. (Ed.) Martin W. Bauer and Massimiano Bucchi. New York: Routledge, Taylor \& Francis Group: 53-70.

Burns, T.; O'Connor, D.; Stocklmayer, S. (2003). Science Communication: A Contemporary Definition. Public Understanding of Science. 12: 183-202.

Cook, D. M.; Boyd, E. A.; Grossmann, C.; Bero, L. A. (2009). Journalists and conflicts of interest in science: beliefs and practices, Ethics In Science And Environmental Politcs / Ethics Sci Environ Polit. Published online April 28: 1-8.

COSCE (2005). Acción CRECE. Comisiones de Reflexión y Estudio de la Ciencia en España (Proposal by the Scientific Community to boost Science in Spain), by Confederación de Sociedades Científicas de España (COSCE), Erişim: https:// www.upf.edu/pcstacademy/_docs/cosce_en_02.pdf. Tarih: 02.06.2018.

de Semir, V. (2000). Scientific journalism: Problems and perspectives. Internatl Microbiol. Vol 3: 125-128.

Dimopoulos, K.; Koulaidis, V. (2002). The socio-epistemic constitution of science and technology in the Greek press: an analysis of its presentation. Public Understanding of Science. 11(3): 225-241. 
Dunwoody, S. (2014). Science journalism / Prospects in the digital age. Routledge Handbook of Public Communication of Science and Technology. (Ed.) Massimiano Bucchi and Brian Trench. London: Routledge: 27-29.

Dursun, Ç. (2010). Dünyada Bilim Illetişiminin Gelişimi ve Farklı Yaklaşımlar: Toplum İçin Bilimden Toplumda Bilime, Kurgu, Anadolu Üniversitesi Yayınları: 1-35.

Egikova, V. (2009). Russian science journalism: the past and the future. Ethics In Science And Environmental Politcs / Ethics Sci Environ Polit. Vol 9: 29-32.

Elias, C. (2007). The use of scientific expertise for political PR / The 'Doñana' and 'Prestige' cases in Spain. Journalism, Science and Society. (Ed.) Martin W. Bauer and Massimiano Bucchi. New York: Routledge, Taylor \& Francis Group: 227-238.

Elmer, C.; Badenschier, F.; Wormer, H. (2008). Science for everybody? How the coverage of research issues in German newspapers has increased dramatically. Journalism \& Mass Communication Quarterly. 85(4): 878-893.

Erdoğan, í. (2007). Türkiye'de Gazetecilik ve Bilim İletişimi, Yapısal Özellikler, Sorunlar ve Çözüm Önerileri, G. Ü. İletişim Araştırmaları Merkezi Kırkıncı Yıl Kitaplığı No: 7. Ankara.

European Commission. (2007). Science, Society and Politics Knowledge Societies from a Historical Perspective. Reported by Dominique Pestre. Office for Publications of the European Communities.

Fahy, D.; Nisbet. M. C. (2011). The science journalist online: Shifting roles and emerging practices. Journalism. 12(7): 778-793.

Fjæstad, B. (2007). Why journalists report science as they do. Journalism, Science and Society. (Ed.) Martin W. Bauer and Massimiano Bucchi. New York: Routledge, Taylor \& Francis Group: 123-131.

Franklin, J. (2007). The end of science journalism. Journalism, Science and Society. (Ed.) Martin W. Bauer and Massimiano Bucchi. New York: Routledge, Taylor \& Francis Group: 143-156.

Fuller, S. (1999). The governance of science: ideology and the future of the open society. USA: Philadelphia. Open University Press.

Gelmez Burgazgil, S. (2017). Kritik Olaylar, Politik Dokümanlar, Raporlar ve Araştırmalar Işığında Türkiye'de Bilim Illetişimi, Selçuk İletişim, 10 (1): 232-261.

Govoni, P. (2007). Science communication in late nineteenth century Italy. Journalism, Science and Society. (Ed.) Martin W. Bauer and Massimiano Bucchi. New York: Routledge, Taylor \& Francis Group: 21-32.

Göpfert, W. (2007). The strength of PR and the weakness of science journalism. Journalism, Science and Society. (Ed.) Martin W. Bauer and Massimiano Bucchi. New York: Routledge, Taylor \& Francis Group: 215-226.

Gunnell, J. G. (2009). Ideology and the philosophy of science: an American mi- 
sunderstanding. Journal of Political Ideologies. Vol 14-3: 317-337.

Kennedy, D. (2010). Science and the Media. Science and the Media. (Ed.) Donald Kennedy and Geneva Overholser. Cambridge: American Academy of Arts and Sciences: 1-11.

Kurath, M.; Gisler, P. (2009). Informing, involving or engaging? Science communication, in the ages of atom-, bio- and nanotechnology. Public Understanding Science: 18 (5), 559-573.

Lieverouw, L. (1990). Communication and the Social Representation of Scientific Knowledge. Critical Studies in Mass Communication. 7: 1-10.

Metcalfe, J \& Gascoigne, T. (1995). Science journalism in Australia, Public Understanding of Science, 4 (4): 411-428.

Metcalfe, J.; Gascoigne, T. (1995). Science journalism in Australia. Public Understand. Sci. 4: 411-428.

Nelkin, D. (1987). The Culture of Scinece Journalism. Society. Vol 24-6: 17-25.

Nelkin, D. (1995). Selling Science: How the press cover science and technology. USA: New York, Freeman.

Nyhan, B.; Sides, J. (2011). How Political Science Can Help Journalism (and Still Let Journalism Be Journalists). The Forum. Vol 9-1. Article 2.

O'Neill, G. (1991). Science writing: the 17th sunrise industry. Search. 22(6).

Pitrelli, N. (20147). Science journalism: In search of a new identity. Medical Writing. Vol 26-2: 41-44.

Rehman. J. (2013). The need for critical science journalism. The Guardian. 16 Mayıs.

Richter, B. (1995). The Role of Science in Our Society. USA: Stanford Linear Accelerator Center of Stanford University (Konferans Sunumu): 1-10.

Royal Society. (2010). The Scientific Century: securing our future prosperity. The Royal Society Science Policy Centre. UK: London.

Russell, C. (2010). Covering Controversial Science: Improving Reporting on Science and Public Policy. Science and the Media. (Ed.) Donald Kennedy and Geneva Overholser. Cambridge: American Academy of Arts and Sciences: 13-43.

Schumpeter, J. A. (1949). Science and Ideology. The American Economic Review. Vol. 39, No. 2: 346-359.

Secko, D. M.; Amend, E.; Friday, T. (2013). Four Models of Science Journalism: A synthesis and practical assessment. Journalism Practice. Vol 7-1: 62-80.

Selvaraj, S; Borkar, D.S.; Prasad, V. (2014). Media Coverage of Medical Journals: Do the Best Articles Make the News?. PLoS ONE: 9(1): e85355. https://doi. org/10.1371 
Shäfer, M. (2010). Taking stock: A meta-analysis of studies on the media's coverage of science. Public Understanding Science. 21(6): 650-663.

Sheets-Pyenson, S. (1985). Popular science periodicals in Paris and London: The emergence of a low scientifi c culture 1820-1875. Annals of Science. 42 (6): 549-572.

Summ, A.; Volpers, A.M. (2016). What's science? Where's science? Science journalism in German print media. Public Understanding of Science (Sage). Vol 25(7): 775-790.

Thee, M. (1971). The Scientist's Role in Society / An Outline of a Strategy. Security Dialogue. Volume: 3-4: 367-370.

Tiryaki, S. (2018). “Internet Gazetelerinde Bilim ve Teknoloji Haberlerinin Sunumu", Uluslararası Dijital Çağda Illetişim Sempozyumu, 18-19 Ekim, Mersin (Sözlü Sunum).

Tobey, R. J. (1993). The American ideology of natural science. Biology and Philosophy. Vol 8: 103-108.

Treise, D.; Weigold, M. (2002). Advancing Science Communication: A Survey of Science Communication. Science Communication. Vol 23: 310-322.

Trench, B. (2007). How the internet changed science journalism. Journalism, Science and Society. (Ed.) Martin W. Bauer and Massimiano Bucchi. New York: Routledge, Taylor \& Francis Group:133-141.

Turney, J. (2007). The latest boom in popular science boks. Journalism, Science and Society. (Ed.) Martin W. Bauer and Massimiano Bucchi. New York: Routledge, Taylor \& Francis Group: 82-91

Utma, S. (2015). Bilim İletişimi ve Bilim Gazeteciliği: Ege Üniversitesi Haber Ajansı Örneğinde Üniversitelerde Bilim Haberlerinin Üretilmesine Yönelik Bir İnceleme, Ege Üniversitesi Sosyal Bilimler Enstitüsü Gazetecilik Anabilim Dalı, Yayınlanmamış Doktora Tezi.

Utma, S. (2017). Bilimsel Okuryazarlık: Bilim İletişimi ve Medyadaki Bilim Haberlerini Doğru Okumak, Uluslararası Sosyal Araştırmalar Dergisi, 10 (50): 788-799.

Uysal, A.E. (2017). An Evaluation of Health News in Turkey in Terms of Media Ethics and Science Journalism. Review of Journalism and Mass Communication. Vol 5-1: 34-60.

Vestergård, G. L. (2016). Where does science news come from? (An industrial $\mathrm{PhD}$ thesis on the ecosystem of science news Gunver Centre for Science Studies). Aarhus University and Experimentarium Science Center. Denmark: SUN-TRYK.

Wormer, H. (2008). Science journalism. (Ed.) W. Donsbach. The International Encyclopedia of Communication Online. Wiley-Blackwell Publishing: 4512-4514. 
Yıldırım Becerikli, S. (2013b). Bilim Teknoloji ve Yenilik Haberleri Okurluğu: Gelir Düzeyi Değişkeni Üzerinden Bir Alımlama Çalışması, II. International Conference on Communication, Media, Technology and Design: 402-405.

Yıldırım Becerikli, S.(2013a). Türkiye'deki Bilim Teknoloji Yenilik Habercilerinin Profili ve Haber Yapma Pratikleri Üzerine Düşünmek, İstanbul Üniversitesi Illetişim Fakültesi Dergisi: 1-18. 